\title{
REVIEW OF THE LATE OLIGOCENE FLORA OF MATRÝ NEAR SEBUZÍN (ČESKÉ STŘEDOHOŘÍ MTS., THE CZECH REPUBLIC)
}

\author{
ZLATKO KVAČEK ${ }^{1, *}$, VASILIS TEODORIDIS ${ }^{2}$, MIROSLAV RADOŇ $^{3}$
}

\author{
'Institute of Geology and Palaeontology, Faculty of Science, Charles University, Albertov 6, 12843 Praha 2, the Czech Republic; e-mail: \\ zlatko.kvacek@gmail.cz. \\ 2 Department of Biology and Environmental Studies, Faculty of Education, Charles University, Magdalény Rettigové 6, 116 39 Praha 1, the \\ Czech Republic; e-mail: vasilis.teodoridis@pedf.cuni.cz. \\ ${ }^{3}$ Regional Museum in Teplice, Zámecké náměstí 14, 41513 Teplice, the Czech Republic; e-mail: rmtep@seznam.cz. \\ ${ }^{*}$ corresponding author
}

Kvaček, Z., Teodoridis, V., Radoň, M. (2018): Review of the late Oligocene flora of Matrý near Sebuzín (České středohoří Mts., the Czech Republic). - Fossil Imprint, 74(3-4): 292-316, Praha. ISSN 2533-4050 (print), ISSN 2533-4069 (on-line).

\begin{abstract}
The Oligocene palaeontological locality on Matrý Hill near Sebuzín in the České středohoří Mts., North Bohemia, belongs to the Děčín Formation and is dated to 30.8-24.7 Ma according to the regional stratigraphy. It has yielded, in addition to insects from the Heteroptera group, a fossil bee Apis petrefacta and palaeobatrachid frogs, also numerous plant remains. Their recovery began in 1996. The plant fossil assemblage consists mostly of leaf impressions, occasionally accompanied by casts or impressions of fruits. Noteworthy are records of a fern Woodwardia muensteriana, conifers Pinus cf. rigios, P. cf. hepios, Calocedrus suleticensis, Tetraclinis salicornioides, Torreya bilinica, cf. Cephalotaxus parvifolia and numerous angiosperms, e.g. Liriodendron haueri, Daphnogene cinnamomifolia, Platanus neptuni, Cercidiphyllum crenatum, Sloanea artocarpites, Ulmus pyramidalis, Celtis pirskenbergensis, Carya fragiliformis, C. quadrangula, Betula brongniartii, B. dryadum, Alnus rhenana, A. cf. kefersteinii, Carpinus grandis, Ostrya atlantidis, Acer crenatifolium, A. cf. palaeosaccharinum, A. integrilobum and Craigia bronnii. Several angiosperm foliage specimens of both monocots and dicots have not yet been identified to a particular genus and species. The fossil plant assemblage at Matrý corresponds to two vegetation types, i.e. azonal riparian forest and zonal mixed mesophytic forest, as corroborated by the Integrated Plant Record vegetation analysis. The vegetation thrived undera humid climate, characterized by average values of MAT $\left(13.4{ }^{\circ} \mathrm{C}\right)$, WMMT $\left(23.8^{\circ} \mathrm{C}\right), \mathrm{CMMT}\left(3.6^{\circ} \mathrm{C}\right)$ and $\mathrm{MAP}(1,117$ $\mathrm{mm})$. The Matry fossil flora is similar in composition to the flora of Žichov from the same Oligocene Děčín Formation in the České středohoří Mts.
\end{abstract}

Key words: plant, animal, fossils, České středohoří Mts., North Bohemia, late Oligocene

Received: October 4, 2018, | Accepted: November 20, 2018 | Issued: December 28, 2018

\section{Introduction}

The palaeontological locality on the slope of Matrý Hill near Sebuzín in the North Bohemian volcanic belt of the České středohoří Mts. has been known since its discovery by Miroslav Radoň in 1996 (Radoň 2001, 2002, Radoň et al. 2006). This relatively new site in North Bohemia has not yielded numerous fossils but may fill the gap in the stratigraphical succession of palaeontological localities in Central Europe (see Akhmetiev et al. 2009). So far, several monographic treatments of the flora of the České středohoří Mts. have been produced (e.g. Kvaček 2002, Kvaček and Teodoridis 2007) and may serve as a basis for wider comparisons of environment changes during the Palaeogene in Central Europe.

Collecting activities in this locality have continued since its discovery in 1996 until the present. Radoň (2002) reported on the flora of the area and gave a detailed account on the so far recovered fossils together with geological and palaeontological data from the adjacent sites of Holý Kluk, Kundratice, Roudný, Trupelník, Řisuty, Sedlo, Rytina, Skalice, Větruše and Žežice. Later, Sedláčková (2004) produced an idealized geological section of the outcrop and described in detail sedimentology. Soukupová (2004) published the first evaluation of the vegetation and environment, and Akhmetiev et al. (2009) published a review of the flora together with that from the adjacent sites and compared it with similar volcanic floras of the Sikhote Alin' in the Far East of Russia. Since 2009 no further detailed study has appeared characterizing this interesting palaeontological locality. Before a monograph of the palaeontology of the České středohoří Mts. can be published for the wider audience in the Czech Republic 

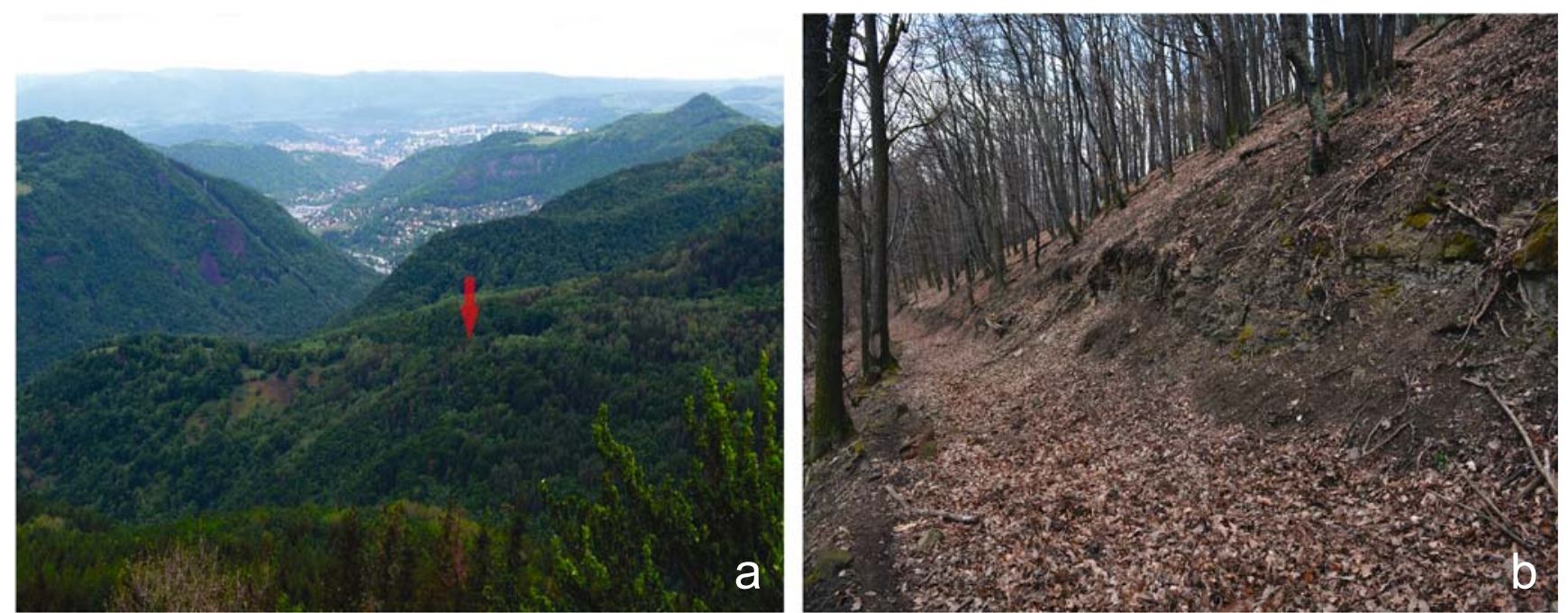

Text-fig. 1. (a) View downslope from the Matrý Hill (locality indicated by red arrow). (b) Sampling outcrop of tuffitic aleuropelite rich in plant macrofossils.

(Dvořák and Radoň in prep.), the present study is required as it contributes new material on the characteristics of the Palaeogene, namely its flora in this region (see Radoň 2001, 2002, Radoň et al. 2006).

\section{Geological and palaeontological overview}

The site at Matrý (formerly Marterey, Matrai; GPS: $50^{\circ} 36^{\prime} 8.475^{\prime \prime} \mathrm{N}, 14^{\circ} 5^{\prime} 20.183^{\prime \prime} \mathrm{E}$ ) is on a small volcanic hill of height $593.9 \mathrm{~m}$. It is situated $2.5 \mathrm{~km} \mathrm{NE}$ of the village of Sebuzín and $5.5 \mathrm{~km} \mathrm{SSE}$ of the town of Ústí nad Labem (Kvaček and Walther 1998: 3, text-fig. 2). It is formed by effusions of compact and alternate-brecciaed olivine basaltoids and non-olivinic basalts intruded into volcaniclastic rocks. The locality belongs to the Děčín Formation (sensu Cajz 2000) and is assigned to the upper Oligocene part of the České středohoří volcanic complex. The fossiliferous layers crop out on the slope within trachybasaltic pyroclastics in interchanging grey, fine grained tuffite and thinly bedded diatomite (see Text-fig. 1). According to Sedláčková (2004), the sedimentation is cyclic due to volcanic activity and climate changes. Three regular cycles and one uppermost inverse cycle could be identified here (Sedláčková 2004). Each cycle began with coarse-grained tuffitic psammite. Upwards various numbers of rhythms have been laid down in positive gradation. The top of the cycles are represented by red to brown silty tuffite which were deposited in calm water containing thin layers of diatomite. The third cycle includes a layer of tuffitic psammite with silty lenses which may indicate the beginning of the inverse cycle. This cycle also includes the fossiliferous layer formed by tuffitic diatomite.

The Děčín Formation, dated to 30.8-24.7 Ma, on Matrý Hill is overlain at the top of the hill by olivine-rich lava flow of the Dobrná Formation, which is 24.0-19.3 Ma in age (Cajz 2000), however it covers the fossiliferous layer. Radiometric dating of the rocks directly connected to the fossiliferous layer, which was deposited shortly before the upper limit of the Děčín Formation, is still required.
Freshwater sedimentation can be proven by the presence of fossil crayfish fauna and the not yet worked out Heteroptera insects belonging to either Notonectidae or Corixidae ( $\mathrm{J}$. Prokop, pers. com.). A fossil honeybee Apis petrefacta RADOŇ (Radoň 2014) must be added to the list of fauna which also includes three incomplete frog skeletons belonging, according to Z. Roček (pers. com.), to palaeobatrachids (Palaeobatrachus sp.). In the diatom flora, centric types of Melosira dominate (Řeháková 1967). Sedláčková (2004) also noted Campelodiscus sp. (determination by Dr. Václav Houk).

\section{Material and methods}

The fossil leaves studied are preserved as impressions. Attempts to obtain epidermal structures from these impressions failed. Identifications of the palaeobotanical material relies on gross morphological features. A small part of the plant fossils represents fruits, often preserved as casts. Most of the material was collected by the third author with the aid of collaborating colleagues over several visits to the site from 2000 until the present. The studied specimens are housed in the Regional Museum in Teplice and partly illustrated by Radoň (2002: photos 4-6, pls 1-3). The collections used by Soukupová (2004), who participated in collecting and described some material in her $\mathrm{PhD}$ thesis, is partly housed in the Regional Museum in Teplice. The palaeozoological part of the collection was partly published as noted above, and further will be described separately in collaboration with specialists from abroad.

The first preliminary lists of fossil plant taxa appeared in a review of the flora of the České středohoři Mts. by Radoň (2001, 2002). Kvaček and Walther (1998: 3) noted younger aspects of this flora recovered by Radon near the top of Matrý Hill. This was later the subject of Soukupová's PhD thesis (2004) and a collaborative account by Akhmetiev et al. (2009). In her thesis, Soukupová (2004) lists 21 taxa with specimen frequencies. The present treatment is based on the collection made by the third author including recent additions. 


\section{Systematic palaeobotany}

The arrangement of taxa follows the system introduced by the Angiosperm Phylogeny Group IV (APG IV 2016).

\section{Ferns}

Blechnaceae C.PresL

Woodwardia SM.

Woodwardia muensteriana (C.Presl in STERnb.) KRäUSEL Pl. 1, Figs 1-2

1838 Pecopteris muensteriana C.PresL in STERnB., p. 154, pl. 36, fig. 2.

1921 Woodwardia muensteriana (C.Presl in SternB.) KRÄUSEL, p. 336, pl. 11, figs 2, 6-8, pl. 12, fig. 4.

2009 Woodwardia muensteriana (C.PresL in STERnB.) KräUSEL; Akhmetiev et al., pp. 96, 117, pl. 12, fig. 10.

Material studied. Sterile pinna PA 1428.1, 1428.2 (counter-impression).

Description. A fragmentary serrate pinna which shows characteristic areolation of the medial venation and thus allows safe identification of this sterile fern fragment.

D i s c u s s i o n. This fern was occasionally noted in the Palaeogene of the České středohoří Mts. in tuffitic deposits near Březiny (Birkigt) - see the published, but not illustrated, records by Engelhardt (1891; as Woodwardia roessneriana Heer). Its main record in the Czech Republic is centred in the early Miocene deposits of the Most Basin, namely in the Most Formation (Bůžek 1971, Hurník 1978).

\section{Conifers}

Pinaceae Spreng. ex F.RudolPhi, nom. cons.

\section{Pinus L.}

\section{Pinus cf. rigios (Unger) EtTINGSh.} P1. 1, Figs 5-6

cf. 1850 Pinites rigios Unger, p. 362.

cf. 1852 Pinites rigios UNGER; Unger, p. 25, pl. 13, fig. 3 (holotype).

cf. 1866 Pinus rigios (Unger) Ettingsh., p. 41, pl. 13, figs 11-12. 2009 Pinus rigios (Unger) EtTingsh.; Akhmetiev et al., p. 96, pl. 12, fig. 1.

Material studied. Needle leaves PA 1159.1, 1159.2, 1348 .

Description. Needles in fascicles of three were recovered from several impressions. The longest incomplete needles attain well over $100 \mathrm{~mm}$ in length; the cross section is triangular, the largest diameter being ca. $1 \mathrm{~mm}$. The sheath is over $10 \mathrm{~mm}$.

D i s c u s s i o n. Such needles occur associated with seed cones of Pinus engelhardtii Menzel in the early Miocene of the Most Formation ("Břešt'any Clay") (see Kvaček et al. 2004). The fossil species from there was described by Unger (1850, 1852; as Pinites rigios - see Hably et al. 2001) and reported repeatedly from the early Miocene deposits of North Bohemia. The occurrence of pine foliage in ternate fascicles from the České středohoří Mts. is rare, namely found at Žichov (Ettingshausen 1866: 41, pl. 13, fig. 11; as
Pinus taedaeformis (Unger) EtTINGSh., frequently assumed as a synonym of P. rigios - e.g. Mai 1999).

\section{Pinus cf. hepios (Unger) HeER}

P1. 1, Figs 3-4

1850 Pinites hepios Unger, p. 362.

1855 Pinus hepios (Unger) HeER, p. 57, pl. 21, fig. 1.

Material studied. Needle leaves PA 1160.1, 1188.1, 1185.1, 1328, 1347.

Description. Several needles over $100 \mathrm{~mm}$ long, half-moon in cross section and joined in fascicles of two and partly attached to a short sheath.

Discussion. Similar sterile needles attached to shoots are known from the Doupovské hory Mts. recovered at Valeč (Menzel 1901; as Pinus hepios Unger; Brabenec 1909: 48, text-fig. 29; as Pinus hepios Unger. sp.).

\section{Cupressaceae GraY, nom. cons.}

\section{Calocedrus KURZ}

\section{Calocedrus suleticensis (BRABENEC) KVAČEK} Pl. 1, Figs 12-13

1909 Libocedrus suleticensis BRABENEC, p. 60, text-fig. 42.

1999 Calocedrus suleticensis (BRABENEC) KVAČEK, p. 241, figs 1-6, 16-26.

2009 Calocedrus suleticensis (BRABENEC) KVAČEK; Akhmetiev et al., p. 96, pl. 12, fig. 6 .

Material studied. Seed cone PA 1173.1.

D e s c ription. A fragmentary seed cone with a short stalk fragment.

$\mathrm{D}$ i s c u s s i o n. The single specimen at hand shows the typical characters of this rare fossil conifer, namely the oval part of the seed cone and decussate phyllotaxy of broad, but not fused scale leaves. This incomplete specimen clearly matches the type material from Suletice, a site not far from Matrý (Kvaček and Walther 1995, Kvaček 1999), from where more complete material of this species is known.

\section{Tetraclinis MASTERS}

\section{Tetraclinis salicornioides (UNGER) KVAČEK Pl. 1, Figs 10-11}

1989 Tetraclinis salicornioides (UNGER) KVAČEK, p. 48, pl. 1, fig. 11 , pl. 2, figs $2-14$, pl. 3, figs $1-4$, pl. 7, figs 3-4, text-fig. 1 .

2002 Tetraclinis salicornioides (UNGER) KVAČEK; Radoň, p. 170, pl. 1, fig. 9 .

2009 Tetraclinis salicornioides (UNGER) KVAČEK; Akhmetiev et al., p. 117.

Material studied. Seed PA 1177 and a fragment of leaf segment, PA 1427.

Description. The seed showing two basally orientated wings, a fragment of the cladode-like leaf segment with fully fused decussate scale leaves.

D i s c u s s i o n. This well-known fossil conifer occurs but rarely in other Palaeogene sites of North Bohemia (Kučlín, Valeč, Kundratice, Suletice - see Kvaček and 
Teodoridis 2011) and more abundantly in the Miocene deposits connected with the climatic optimum (e.g. Holý et al. 2012).

\section{Taxaceae GraY}

\section{Torreya RAF.}

\section{Torreya bilinica SAPORTA et MARION}

Pl. 1, Figs 8-9

1876 Torreya bilinica SAPORTA et MARIOn, p. 221.

2009 Torreya bilinica SAPORTA et MARION; Akhmetiev et al., p. 96 , pl. 12, fig. 8 .

Material studied. Needle leaf impressions PA 1358, PA 1392.1, PA 1584.

Description. Isolated needles which are rounded on the apex, flat and characterized by distinct very narrow longitudinal stomatal bands on the abaxial side.

$\mathrm{D}$ is cuss ion. This conifer was recovered in several other Palaeogene sites in North Bohemia and the surrounding areas, e.g. at Seifhennersdorf, Saxony, Germany (Walther and Kvaček 2007). It is typified by a leafy twig from Žichov with attached needles of the same kind (Kvaček 1984, Hably et al. 2001).

Cephalotaxus Siebold et Zuccarini ex EndL.

\section{cf. Cephalotaxus parvifolia (H.WALTHER) KvaČEK et H.W ALTHER Pl. 1, Fig. 7}

? 1964 Amentotaxus parvifolia H.WALther, p. 8, pl. 1, figs 1-5. ? 1998 Cephalotaxus parvifolia (H.WALther) KvaČEK et H.WALther, p. 11, pl. 4, figs 1-3.

Material studied. Needle leaf PA 1393.

D e s c ri p t i o n. A flat lineal needle, $2.5 \mathrm{~mm}$ wide and $15 \mathrm{~mm}$ long with an acute apex and no traces of stomatal areas.

Discussion. The single specimen at hand matches the type from the early Oligocene site Seifhennersdorf (Walther and Kvaček 2007) in overall morphology. The identification is uncertain without anatomical evidence. This conifer occurs but rarely in the neovolcanic area of North Bohemia (Kundratice) to Saxony (Seifhennersdorf).

\section{Angiosperms \\ Magnoliaceae Juss., nom. cons.}

\section{Magnolia L.}

\section{aff. Magnolia seifhennersdorfensis H.WALTHER et KvačEK}

$$
\text { Pl. 2, Figs 1-3 }
$$

2002 cf. Magnolia sp.; Radoň, p. 171, pl. 2, fig. 6.

2007 Magnolia seifhennersdorfensis H.WALTHER et KVAČEK, p. 94, pl. 3, figs $1-2$, pl. 22, figs 8-10.

Material studied. Leaf impressions PA 1195.1-3, $1367,1371,1448$.

Description. The leaf impressions are entiremargined, all incomplete and without cuticles. All have a narrow elliptical blade, about 20-35 mm wide, short petiole, with cuneate base and acute apex and with eucamptodromous venation.

Discussion. The affinity to Magnolia seifhennersdorfensis is suggested on type locality by the occurrence of seeds described as Magnolia cf. denudataeformis P.I.Dorof. (Walther and Kvaček 200: pl. 2, figs 3-4). Identification of the leaf material at hand is not quite certain because various Lauraceae leaves are similar in gross morphology.

\section{Liriodendron $\mathrm{L}$}

\section{Liriodendron haueri ETTINGSH.}

P1. 2, Figs 4-8

1976 Liriodendron haueri EtTingsh.; Bůžek et al., p. 84, pl. 2, figs $12-15$, pl. 3 , figs $1-8$, pl. 15, figs $3-4$, text-figs 3 , 4a-c.

2002 Liriodendron procacinii UNGER; Radoň, p. 171, pl. 2, fig. 9.

2009 Liriodendron haueri EtTingsh.; Akhmetiev et al., p. 96, pl. 12 , fig. 7 .

Material studied. Leaves PA 1187, 1357, 1399, 1400, 1401.1, 1440.1 and fruitlets PA 1359.1, 1359.2, $1426.1,1442$.

Des cription. The leaves are short petiolate, lamina shallowly bilobate, 40-60 mm long, 30-60 mm wide, lobes at wide angles, entire-margined, acuminate, base widely rounded. Associated fruitlets represent isolated winged samaras, with elongate wing and basally positioned, $2 \mathrm{~mm}$ long spindle-shaped seed part.

Discussion. The recovered foliage is a complete record of Liriodendron haueri from North Bohemia. This fossil species is based on a single fragmentary leaf of the same kind recovered at Žichov (Ettinghausen 1869, Hably et al. 2001). Associated fruitlets correspond to those described in detail from the Oligocene site Markvartice (Bůžek et al. 1976).

\section{Lauraceae Juss., nom. cons.}

\section{Laurophyllum GöPP.}

\section{Laurophyllum sp.}

$$
\text { P1. 3, Figs 1-7 }
$$

2002 Laurophyllum sp.; Radoň, pp. 170-171, pl. 1, fig. 6, pl. 2, figs $1-2$.

Material studied. Leaf impressions PA 1158.2, 1158.6, 1158.7, 1158.8, 1182.1 1182.3, 1189.2, 1189.4, 1349, 1383.1, 1398, 1584.

Description. Impressions of entire-margined pinnately veined leaves with lanceolate blade, acuminate apices and narrow cuneate bases.

Discussion. Such leaf remains occur but rarely in the Matrý plant assemblage. They resemble various fossil species based on details of cuticle structure, such as Laurophyllum pseudoprinceps WeYLAND et KILPPER, Laurophyllum medimontanum BŮŽEK, HoLÝ et KVAČEK and Laurophyllum acutimontanum MAI (Kvaček and Walther 1998). 


\section{Daphnogene UNGER}

\section{Daphnogene cinnamomifolia (BRONGN.) UNGER f. lanceolata (UNGER) KVAČEK et H.WALTHER}

Pl. 4, Figs 1-4

1998 Daphnogene cinnamomifolia (BRONGN.) UNGER forma lanceolata (Unger) KVAČEK et H.WALTHER, p. 13, pl. 5, figs 6-7, text-fig. 13.8.

2002 Daphnogene cinnamomifolia (BRONGN.) UnGER; Radoň, p. 164 , photo 6 below, pl. 1, figs 4-5, pl. 2, fig. 8 .

2009 Daphnogene cinnamomifolia (BRONGN.) UnGER; Akhmetiev et al., pp. 96, 170-171, pl. 12, fig. 9.

Material studied. Leaf impressions PA 1153.1-2, 1167.1-6, 1174.1-4, 1345, 1346, 1350, 1363.1 (leafy twig), 1373, 1376.1-2, 1395, 1408.

Description. The leaves are alternately attached, short petiolate, lamina narrow lanceolate, with suprabasal acrodromous venation. Broader leaf forms (PA 1174.1, 1395) are the exception.

$\mathrm{D}$ iscussion. This laurophyllous representative of Lauraceae occurs quite commonly and in leaf morphology fits within this narrow-leaved lauroid fossil species, usually assigned to Cinnamomum SCHAEFF. It is widely distributed in the Palaeogene localities in North Bohemia.

\section{? Typhaceae Juss., nom. cons.}

\section{? Sparganium L.}

? Sparganium sp.

$$
\text { Pl. 4, Fig. } 5
$$

Material studied. Leaf impression PA 1424.1., 1424.2 .

D e s c r i p t i o n. The leaf fragments are parallel veined, comprising a $2 \mathrm{~mm}$ thick main vein and regularly spaced parallel lateral veins $1-2 \mathrm{~mm}$ thick. The veins are denser near the margin which is smooth. No cross veins were observed.

$\mathrm{D}$ i s c u s s i o n. Such leaf impressions have only rarely been encountered in the plant assemblages of the České středohoří Mts. Such monocot leaf remains cannot be safely identified to a particular genus but indicate the possible proximity of an aquatic environment. Similar but much wider leaf remains from the Miocene deposits of North Bohemia and elsewhere are often assigned to the fossil species Typha latissima A.BRAUN (Kvaček and Hurník 2000).

\section{? Gramineae Juss., nom. cons. \\ ? Gramineae gen. et sp. indet. Pl. 4, Fig. 6}

Material studied. Leaf impression PA 1168.1.

Description. Parallel-veined grass-like leaf fragments have been found very rarely in the Matrý leaf assemblage. They are irregularly split along the length.

$\mathrm{D}$ is c u s s i o $\mathrm{n}$. The fossil at hand resembles the foliage of Gramineae. An affinity to any particular genus of other monocots is uncertain.
Platanaceae T.LeSTIB., nom. cons.

\section{Platanus L.}

\section{Platanus neptuni (EtTINGSH.) BŮžEK, HolÝ et KvačEK} Pl. 4, Figs 7-10

1866 Sparganium neptuni EtTingsh., p. 31, pl. 7, figs 9-15.

1967 Platanus neptuni (Ettingsh.) BưžEK, HolÝ et KvaČEK, p. 205, pls $1-4$.

2002 Platanus neptuni (EtTingsh.) BŮžEK, HolÝ et KvaČEK; Radoň, p. 170, pl. 1, figs 7-8, pl. 2, figs 3-4.

Material studied. Leaves PA 1157.4, $1179.1,1180.1,1180.2,1355,1362,1417,1447,1450$; infructescences PA 1434, 1435; stipules PA 1364.1, 1179.2.

D e s c ription. The fragmentary leaves are simple or ? trifoliate (Pl. 4, Fig. 7), obovate, 37-42 mm long and 7-11 $\mathrm{mm}$ wide, on the margin widely blunt regularly toothed, partly entire, venation semicraspedodromous, partly eucamptodromous. Female infructescence globular, ca. 10 $\mathrm{mm}$ in diameter, composed of narrow fruitlets projected by a short style out of the infructescence. Strap-like stipules parallel-veined, cut at the base.

D is c us sion. The record of Platanus neptuni from Matrý includes mostly simple leaves, in one case a trifoliate foliage is also recognized in some other sites, e. g. at Kučlín (Kvaček and Teodoridis 2011). The infructescences corroborate the wide distribution of this element in other Palaeogene sites in Central Europe (Kvaček and Manchester 2004).

Cercidiphyllaceae EngL., nom. cons.

Cercidiphyllum Siebold et ZuCC.

Cercidiphyllum crenatum (UNGER) R.W.BR. Pl. 5, Fig. 1

1850 Dombeyopsis crenata UnGER, p. 448.

1935 Cercidiphyllum crenatum (UNGER) R.W.BR., p. 575, pl. 68, figs $1,6,8-10$.

Material studied. Leaf impressions PA 1352, 1406, 1581 .

D e s c ription. The isolated leaves are deeply cordate, widely elliptic to round with finely crenate to crenulate margin.

Discussion. The recovered foliage in gross morphology clearly matches the other records widely distributed in the Oligocene floras of the České středohoři Mts. and elsewhere (see Jähnichen et al. 1980, Kvaček and Konzalová 1996).

\section{? Leguminosae Juss.}

\section{? Leguminosae gen. indet.} Pl. 5, Figs 2-4

Material studied. Leaflet impressions PA 1176, 1371, 1381, 1391, 1405.1, 1411.1, 1439.

Description. Isolated leaflets, some with a short petiolule. 
Discussion. Such legume-like foliage is rarely present in the Matrý plant assemblage. Some match the legume leaflets occurring in other volcanic floras (e.g. PA 1176 forma 3 sensu Kvaček and Walther 1998 at Kundratice), but some others are larger (e.g. PA 1371 - cf. Trigonobalanopsis; PA 1411.1 - cf. Sapindus) and may belong to other groups of angiosperms.

\section{Elaeocarpaceae Juss., nom. cons.}

\section{Sloanea $\mathbf{L}$}

\section{Sloanea artocarpites (ETTINGSH.) KVAČEK et HABLY}

$$
\text { P1. 5, Fig. } 5
$$

1869 Quercus artocarpites EtTingsh., p. 63, pl. 55, figs 19-19b.

1976 Dicotylophyllum sparsidentatum BŮžEK, HolÝ et KVAČEK, p. 105 , pl. 10 , figs $1-7$, pl. 20 , figs $5-6$, pl. 21 , figs $1-6$, text-fig. 8.

2001 Sloanea artocarpites (EtTINGSH.) KVAČEK et HABLy in KVAČEK et al., p. 117.

Material studied. Foliage impression PA 1410.1.

Description. An incomplete leaf, without a base, elongate, over $80 \mathrm{~mm}$ long, $40 \mathrm{~mm}$ wide, on margin minutely sparsely denticulate, venation camptosemicraspedodromous, secondaries at base at wider, high up under regular angles.

Discussion. The identification is not corroborated by epidermal structure typical for this fossil species which is often met found in the Oligocene floras of Central Europe (Walther and Kvaček 2007). Similar foliage is known in the early Oligocene sites of Hungary and Slovenia accompanied by fruits of the Sloanea-type (Kvaček et al. 2001).

\section{Ulmaceae Mirb.}

\section{Ulmus L.}

\section{Ulmus pyramidalis GöPP.} Pl. 5, Figs 6-8

1855 Ulmus pyramidalis Göpp., p. 28, pl. 13, figs 10-12.

2002 Ulmus pyramidalis GöpP.; Radoň, p. 162, photo 4 below, p. 170, pl. 1, fig 10.

2009 Ulmus pyramidalis GöPP.; Akhmetiev et al., p. 96, pl. 12, fig. 12.

Material studied. Foliage impressions PA 1154.1-2, 1162.1-2, 1163.6-10, 1170.10 (two leaves on a twig), 1191.2, 1368, 1370, 1379, 1429.

D e s c ri p t i o $\mathrm{n}$. The leaves are shortly petiolate, petiole max. $4 \mathrm{~mm}$ long, blade lanceolate, often slightly asymmetric at base, apex acute, base rounded to shallow cordate, margin finely double serrate to serrate, $40-80 \mathrm{~mm}$ long and 10-20 $\mathrm{mm}$ wide, venation craspedodromous, secondaries quite dense, at an angle of $30-60^{\circ}$.

Discussion. Ulmus pyramidalis is a common Miocene element in North Bohemia (Bůžek 1971), which replaces Ulmus fischeri HEER, a characteristic element in the early Oligocene (e. g. Bechlejovice - Kvaček and Walther 2004) and in the late Oligocene volcanic floras of the České středohoři Mts. The occurrence of Ulmus pyramidalis at Matrý is one of the earliest records in this area.

\section{Cannabaceae Martinov}

\section{Celtis L.}

\section{Celtis pirskenbergensis (ERW.KNOBLOCH) KVAČEK et H.W ALTHER \\ Pl. 5, Figs 9-10}

1961 Celtis begonioides Göpp. var. pirskenbergensis Erw. KNoBloch, p. 273, pl. 6, figs 3, 5, 8 (holotype).

2006 Celtis sp.; Radoň et al., p. 101, pl. 5, figs 5-7.

2007 Celtis pirskenbergensis (ERw.KNOBLOCH) KVAČEK et H.WAlther; Walther and Kvaček, p. 101, pl. 7, figs 1-8, text-fig. 4a-c.

Material studied. Foliage impressions PA 1353, 1438.

Description. The two studied leaves are shortly petiolate, with an ovate to elongate blade; one is oblique at the base, the other slightly asymmetrical, margin coarsely crenate-serrate. Three basal veins arise at acute angles from the lamina base. Details of venation are poorly visible.

Discussion. The material matches other Celtis foliage recovered elsewhere in a few of the volcanic sites of North Bohemia and Saxony (Radoň et al. 2006, Walther and Kvaček 2007). We follow the treatment proposed by Walther and Kvaček (2007) and leave separately other fossil species known from the Neogene, such as Celtis trachytica ETTINGSH.

\section{Juglandaceae DC. ex Perleb, nom. cons. Carya NuTt.}

\section{Carya fragiliformis (STERnb.) KvačEK et H.W ALther} Pl. 6, Figs 1-3

1825 Phyllites fragiliformis STERnB., p. 42, index iconum, pl. 50, fig. 1.

2002 Carya serrifolia (GöPP.) KRÄUSEL; Radoň, p. 171, pl. 2, figs 11-12.

2007 Carya fragiliformis (STERnB.) KVAČEK et H.Walther; Walther et Kvaček, p. 110, pl. 11, figs 1-3, pl. 23, figs 8-10, text-fig. $6 b$.

Material studied. Leaflet impressions PA 1170.6, $1190.1,1190.2$, 1338.1, 1340, 1351, 1385, 1390.1, 1390.2, 1409, 1418, 1339.2 (cf.), 1363.2 (cf.).

Description. Numerous leaflets with oblong, slightly asymmetrical falcate blade, sharply serrate on the margin and with semicraspedodromous to craspedodromous venation.

Discussion. The material corresponds with the holotype of this fossil species based on a single specimen from Žichov (J. Kvaček and Straková 1997, Walther and Kvaček 2007). It is obviously a part of the whole plant that produced fruits described below as Carya quadrangula (КIRCHH.) J.-F.LEROY.

\section{Carya quadrangula (КIRCHH.) J.-F.LeROY Pl. 6, Figs 4-6}

1866 Carya bilinica (Unger) EtTingsh., p. 46, pro parte, pl. 51, figs 4-5.

1978 Carya quadrangula (КIRCHH.) J.-F.LeroY; Mai and Walther, p. 79 , pl. 32, figs 16-19. 
2002 Carya sp.; Radoň, pp. 134, 164, photo 6 above, pl. 2, fig. 10 .

Material studied. Fruit casts PA 1338.1-2, 1164.1, 1365, 1580 .

Description. Casts of fruits three-dimensionally preserved, partly split into halves, ovoid, some apically acuminate, 25-30 $\mathrm{mm}$ long and 15-30 $\mathrm{mm}$ wide.

Discussion. Such fruits were compared with Carya quadrangula by Mai (1981) in his revision of fossil Carya fruits recovered from various sites of the European Palaeogene and Carya rostrata (Schloth.) Schimp. in his revision of the late Oligocene flora of the Rhön Mts. (Mai 2007).

\section{Juglandaceae genus indet.}

Cyclocarya sp. vel Carya sp.

Pl. 6, Figs 7-9

Mat e ria 1 studied. Foliage impressions PA 1170.1, 1170.7, 1170.8, 1366, 1419.

Description. Leaflet impressions similar to the above described specimens, on the margin denticulate, venation semicraspedodromous.

D iscussion. The above listed foliage impressions differ from Carya foliage by the finely denticulate margin and regularly semicraspedodromus venation. The difference between the impressions and Carya fragiliformis is not so pronounced as to lead to an unequivocal identification.

\section{Betulaceae Gray, nom. cons.}

\section{Betula L.}

\section{Betula brongniartii ETTINGSH.} P1. 7, Figs 1-4

1866 Betula brongniartii Ettingsh., p. 46, pro parte, pl. 46, figs 3-4, pl. 47, fig. 1 .

2002 Betula brongniartii EtTingsh.; Radoň, p. 170, pl. 1, figs 12-13, photo 4 above.

2009 Betula brongniartii Etringsh.; Akhmetiev et al., pp. 96, 117, pl. 12, fig. 3 .

Material studied. Leaf impressions PA 1152.1-2, 1155.1-5, 1157.1-2, 1184, 1196.1-2, 1341, 1342, 1381, 1582 .

Description. The leaves are petiolate, lamina broadly ovate, rounded at base, acute at apex to shortly attenuate, double sharply serrate on margin, ca. $80 \mathrm{~mm}$ long and $50 \mathrm{~mm}$ wide.

Discussion. Leaves from Zichov assigned to Betula brongniartii (Hably et al. 2001) match the birch foliage recovered at Matrý, particularly the strongly double serrate margin. In this way the fossil species differs from the smaller delicate leaves of Betula alboides EngelH. (syn. B. buzekii KVAČEK et H.WALTHER) described from the sites at Kundratice and Seifhennersdorf (cf. Kvaček and Walther 1998, Walther and Kvaček 2007).

\section{Betula dryadum BRONGN.}

P1. 7, Figs 5-6

1976 Betula dryadum BRONGN.; Bůžek et al., p. 93, pro parte, pl. 6, figs 4-6.

Material studied. Bracts and fruitlets PA 1420.1, $1432,1437,1446$.

Description. The bracts are tripartite at the very apex, narrow, up to $10 \mathrm{~mm}$ long, $2 \mathrm{~mm}$ wide, fruitlets double winged, $3 \mathrm{~mm}$ long, $4 \mathrm{~mm}$ wide.

D is c u s s i on. The bracts and fruitlet associated with the above foliage obviously belong to the same birch foliage as mentioned above. Bůžek et al. (1976) assigned them to the same fossil species as leaves co-occurring in the diatomite of the locality Markvartice.

Alnus MilL.

\section{Alnus rhenana (P.WeSSEL et C.O.Weber) Winterscheid et KVAČEK \\ Pl. 7, Figs 7-9}

1856 Corylus rhenana P.Wessel et C.O.Weber, p. 134, pl. 22, fig. 5.

2002 Alnus cf. rostaniana SAPORTA; Radoň, p. 170, pl. 1, fig. 11. 2009 Alnus rostaniana SAPORTA; Akhmetiev et al., p. 117, pl. 12, fig. 11.

2014 Alnus rhenana (P.Wessel et C.O.Weber) Winterscheid et KVAČEK, p. 22, pl. 4, figs 1-5, pl. 11, figs 4-6.

Material studied. Leaf impressions PA 1166.1, $1172.4,1175.2$, 1343, 1372, 1375, 1380, 1403, 1404, 1414, 1423.

Des cription. The leaves are ovate to obovate, over $150 \mathrm{~mm}$ long, $50 \mathrm{~mm}$ wide, incompletely preserved, acute at apex, rounded to shallow cordate at base, finely widely serrate on margin.

Discussion. The alder foliage recovered at Matrý is for the first time compared with Alnus rhenana, which is typically long petiolate, obovate and varying in shape from broadly obovate to ovate (Winterscheid and Kvaček 2014). A fossil species based on the leaf impression of Sorbus palaeoaria ETTINGSH. (Ettingshausen 1869) from Žichov also belongs to Alnus rhenana. It differs in the shape of the blade from the narrow elliptic alder leaves assigned to Alnus gaudinii (HEER) ERW.KNOBLOCH et KVAČEK from Seifhennersdorf (Walther and Kvaček 2007) and Kundratice (Kvaček and Walther 1998). The previously used fossil taxon Alnus rostaniana SAPORTA (Akhmetiev et al. 2009) falls into the synonymy of $A$. rhenana together with another alder foliage from the late Oligocene site of Manosque, France (Saporta 1891).

\section{Alnus sp.}

\section{Pl. 8, Figs $1-3$}

? 1971 Alnus sp.; Bůžek, p. 48, pl. 13, fig. 13, pl. 15, figs 1-6. 2009 Alnus gaudinii (HeER) ERW.KNOBloch et KVAČEK; Akhmetiev et al., p. 117.

Material studied. PA 1172.4, 1403, 1404, 1423, 1436, 1578, 1579.1. 
Description. The leaves are oblong elongate, petiolate, with fine denticulate margin.

D i s c u s s i o n. These morphotypes are associated with the above larger leaf forms and may represent only smaller variants of Alnus rhenana. A resolution of its position cannot be made without epidermal studies. Similar leaf forms also occur in the Oligocene site Valeč in the Doupovské hory Mts., where they are associated with alder infructescences described as Steinhauera oblonga C.Presl in Sternb. (J. Kvaček and Straková 1997: 111, pl. 40, fig. 4).

\section{Alnus cf. kefersteinii (GöPP.) UNGER}

$$
\text { Pl. 7, Fig. } 10
$$

? 1836 Alnites kefersteinii Göpp., p. 564-566, pl. 41, figs 1-5, 15$16,18$.

? 1845 Alnus kefersteinii (GöPP.) UNGER, p. 78.

2009 Alnus kefersteinii (Göpr.) UnGER; Akhmetiev et al., p. 117.

Material studied. PA 1161.1-2, 1444.1, 1576.

Description. Ovoid and strongly compressed infructescences.

Discussion. The material at hand is very poorly preserved. Only its overall form allows identifying it as alder female infructescences. The association with foliage of Alnus rhenana suggests that both organs may belong to the same plant element.

\section{Carpinus L.}

\section{Carpinus grandis UNGER}

Pl. 8, Figs 4-6

1850 Carpinus grandis UnGER, p. 408, pro parte (only folia).

2002 Carpinus grandis Unger; Radoň, p. 171, pl. 2, fig. 5.

Material studied. Leaf impressions PA 1158.9, 1163.8, 1344, 1384, 1388, 1402, 1574.

Description. The leaves are oblong oval with fine serrate-dentate margin, venation craspedodromous, secondaries mostly simple, dense, regularly orientated.

Discussion. The above listed impressions in morphology match other records of Carpinus grandis in adjacent sites in North Bohemia (e.g. Kvaček and Walther 1998, Walther and Kvaček 2007). No associated fruit remains have been recovered at Matrý.

\section{Ostrya HiLL \\ Ostrya atlantidis UNGER \\ P1. 8, Figs 7-10}

1850 Ostrya atlantidis UNGER, p. 50.

2002 Ostrya atlantidis Unger; Radoň, p. 171, pl. 2, fig. 13.

Material studied. Leaf impressions PA 1163.1, 3, 5, 1181.1-2, 1377, 1397.1, 1441, 1442, 1577, involucre PA 1583.

D e s c ription. Leaf impressions similar to the above morphotypes but differing in prominently mucronately serrate margin. A single fruit remain of the same fossil species representing an ovate, compressed parallel-veined involucre was recovered in association.
D i s c u s s i o n. Foliage of this fossil species can easily be mistaken for that of Carpinus with only bluntly finely serrate margin (Kvaček and Walther 1998, 2004). A single involucre of the same fossil species of Ostrya was recovered at Matrý and matches other fossils of this sort occurring at Kundratice and Bechlejovice (Kvaček and Walther 1998, 2004).

\section{Sapindaceae Juss., nom. cons.}

Acer $\mathbf{L}$.

Acer crenatifolium EtTINGSH.

P1. 9, Figs 1-2

1869 Acer crenatifolium EtTingsh., p. 20, pl. 45, figs 1, 4.

1975 Acer tricuspidatum BRONN forma crenatifolium (ETTINGSH.) M.Proch. et BưŽEK, pp. 26, 47.

2002 Acer cf. tricuspidatum BronN; Radoň, p. 134, photo 5 above, text-fig. 1.3.

2009 Acer crenatifolium Etringsh.; Akhmetiev et al., pp. 96, 117, pl. 12, figs 2, 5 .

Material studied. PA 1186.2, 1189.3 (?), 1359.2 (?), 1361.1, 1374 (?), 1407 (?).

Description. Trilobate maple leaves, with crenate margin.

D is c u s s i o n. Such maple leaves from Žichov have been described as an independent species Acer crenatifolium EtTingsh. Procházka in his revision reduced it to a form of Acer tricuspidatum BRONN forma crenatifolium (ETTINGSH.) M.Proch. et BưžEK (Procházka and Bůžek 1975). No leaf anatomical evidence is so far available to prove the affinity to A. crenatifolium or A. tricuspidatum.

\section{Acer cf. palaeosaccharinum STUR}

Pl. 9, Figs 3, 4, 6

? 1867 Acer palaeosaccharinum STUR, p. 177, pl. 5, fig. 8.

? 1869 Acer dasycarpoidesc HeER; Ettingshausen, p. 19, pro parte, pl. 40 , fig. 3 .

2002 Acer cf. palaeosaccharinum STUR; Radon̆, p. 134, photo 5 below, text-fig. 1.2.

2009 Acer crenatifolium EtTingsh.; Akhmetiev et al., p. 117, pl. 12, fig. 2.

Material studied. Leaf impressions PA 1184.1-2, 1189.1, 1356.

Description. The leaves are deeply tricuspidate, blades from $19 \mathrm{~mm}$ to more than $65 \mathrm{~mm}$ in length and 22 $\mathrm{mm}$ to $74 \mathrm{~mm}$ in width, lobes of almost the same width, with subparallel margins, widely simple to irregularly double dentate.

Discussion. We follow the treatment proposed by Walther and Kvaček (2007: 117) stressing that foliage from the České středohoří Mts. assigned to $A$. angustilobum is difficult to differentiate from some forms of $A$. palaeosaccharinum. Maple leaves with a prominently double dentate middle lobe have usually been assigned to Acer palaeosaccharinum STUR but transitional forms connect them with typical Acer angustilobum with only simple dentation on the main lobe. Both fossil morphotypes are connected with a transition phase. 


\section{Acer integrilobum C.O.WEBER}

Pl. 9, Fig. 8

1852 Acer integrilobum C.O.WeBer, p. 196, pl. 22, fig. 5a-b (non fig. 5c).

2009 Acer integrilobum C.O.WeBer; Akhmetiev et al., p. 96, pl. 12, fig. 4.

Material studied. Leaf impressions PA 1189.2, 1449.

Description. The leaves are trilobate, ca. $20 \mathrm{~mm}$ long and fragmentary in width, lobes entire-margined.

Discussion. Such maple leaves with an almost entire margin are rare in the Oligocene leaf assemblages of the České středohoří Mts. (Walther 1972, Kvaček and Walther 1998).

\section{Acer sp.}

P1. 9, Figs 5, 7

2002 Acer sp.; Radoň, p. 134, pl. 1, fig. 1.

Material studied. Fruits PA 1413.1, 1416, 1575.

Description. Winged double samaras, partly isolated mericarps, 22-45 $\mathrm{mm}$ long, 8-35 mm wide, seed part rounded, 5-7 $\mathrm{mm}$ in diameter.

D is cussion. The connection between fossil maple fruits and foliage has not so far been firmly resolved.

Malvaceae Juss., nom. cons.

Craigia W.W.Sm. et W.E.Evans

\section{Craigia bronnii (UNGER) KVAČEK, BŮžEK et MANCHESTER} Pl. 10, Figs 5-6

1845 Ulmus bronnii UnGER, p. 79, pro parte, pl. 25, figs 2-4 (non fig. 1).

1948 Pteleaecarpum bronnii (UNGER) WeYLAnd, p. 130, pl. 21, fig. 5, text-figs 5-9.

1991 Craigia bronnii (Unger) KvaČEK, BŮžEK et Manchester, p. 522 .

Material studied. Fruits PA 1156.1-2, 1360, 1386.1-2, 1387 (cf.).

D e s c ription. Winged broadly oval to rounded fruit valves $10-12 \mathrm{~mm}$ wide and $12-17 \mathrm{~mm}$ long with spindleshaped medial locule, rarely with a small ovate seed inside. Venation of the wing composed of narrow elongated fields radiating from the locule, steeper in the upper part.

Discussion. These fruit remains conform in size and morphology with other records of the same species, commonly recovered in the Oligocene and Miocene of Central Europe (Kvaček et al. 2004).

Angiosperms inc. fam.

\section{Pungiphyllum Frankenhäuser et V.WiLde \\ Pungiphyllum cf. cruciatum (A.BRAUN) Frankenhäuser et V.WILDE Pl. 10, Fig. 2}

? 1851 Quercus cruciata A.Braun; Stizenberger, p. 76.

? 1995 Pungiphyllum cruciatum (A.BraUn) FrankenhäUSER et V.WILDE, p. 101.
Material studied. Leaf impression PA 1340.

Description. Leaf over $100 \mathrm{~mm}$ long and 40 $\mathrm{mm}$ wide, oblong, at the base the margin is entire, towards the apex it is coarsely widely dentate, venation eucamptodromous to craspedodromous, secondaries at wide angles, intersecondaries exceptional.

D i s c u s s i o n. The same morphotypes occur singly in several Oligocene sites of Europe, in the Czech Republic e.g. at Kundratice, Bechlejovice, Suletice-Berand, and rarely also in the Miocene (see Kvaček and Walther 1981, 2004). Affinities have not been resolved so far. The above described morphotype differs from other records of this peculiar fossil species by its shallow dentate margins and matches Quercus buchii C.O.WEBER (Weber 1852) from the late Oligocene site Rott in Germany.

\section{Dicotylophyllum SAPORTA}

Several morphotypes in the Matrý plant assemblage are not assignable to any well-known fossil genus or species of angiosperm foliage.

\section{Dicotylophyllum sp. 1 \\ Pl. 10, Figs 3-4}

Material studied. Leaf impressions PA 1188.1, 1412.2 (cf. Dicotylophyllum 13 sensu Kvaček and Walther 1998).

D e s c ription. The leaves are petiolate, petiole ca. 15 $\mathrm{mm}$ long, basally broadened, lamina elliptical, apex missing, base rounded, margin entire, venation brochidodromous, midrib stout, straight, secondaries regularly bent at medium angle, intersecondaries exceptional.

Discussion. The foliage described above is difficult to identify with a particular angiosperm genus due to its uniform morphology, even when the epidermal anatomy is known (Kvaček and Walther 1998: 17; as Dicotylophyllum 13).

\section{Dicotylophyllum sp. 2 \\ Pl. 10, Figs $7-8$}

Material studied. Leaf impressions PA 1363.2, 1425.1, 1431.

D e s c r i p t i o $\mathrm{n}$. The leaves are oblong, apex acute, base narrow cuneate, margin sharply densely dentate, venation craspedodromous, midrib straight, secondaries dense, at leaf base at wide angles, higher up at narrower angles.

D iscussion. Such sharply and finely dentate leaf fossils have been assigned to Prinsepia serra (UNGER) Kovar-Eder et KvačEK in the Miocene flora of Parschlug (Kovar-Eder et al. 2004).

\section{Dicotylophyllum sp. 3 \\ Pl. 10, Figs 1, 9}

2002 "Viburnum" atlanticum EtTingSh.; Radoň, p. 171, pl. 2, fig. 7.

Material studied. Leaf impressions PA 1163.1 (cf. Viburnum atlanticum), 1431. 
Description. The leaves are narrow ovate, shortly petiolate, lamina $60 \mathrm{~mm}$ long, $30 \mathrm{~mm}$ wide, ovate to widely lanceolate, base cuneate, apex acute, margin coarsely, partly double serrate, venation semicraspedodromous.

D i s c u s s i o n. Similar leaf forms have been assigned to Ternstroemites spp. (Winterscheid and Kvaček 2014) but a more precise identification would require information on epidermal anatomy.

\section{Dicotylophyllum sp. 4} P1. 10, Figs 10-11

Material studied. Leaf impressions PA 1182.3, 1430, 1585.1.

Description. The leaves are shortly petiolate, lamina 40-50 mm long, 20-30 $\mathrm{mm}$ wide, obovate, base cuneate, apex bluntly acute, margin entire, venation brochidodromous, secondaries regularly spaced.

Discussion. Similar leaf forms occurring at Bechlejovice and Seifhennersdorf have been assigned to Diospyros (Kvaček and Walther 1998, Walther and Kvaček 2007). They may belong to the characteristic quadrisepalous calyces co-occurring at several sites.

\section{Vegetation and palaeoclimatic signals}

The flora of Matrý, preserved as leaf and carpological material, so far includes 34 vascular plant taxa -1 fern, 5 conifers, 28 angiosperms (26 dicots and 2 monocots). According to Soukupová (2004), the fossil plant assemblage at Matrý corresponds to two vegetation types - riparian forest and mixed mesophytic forest. In both vegetation types, taxa producing foliage with dentate margin prevailed (73.5\%). In her analysis she considered 7 and 11 taxa, respectively. Most elements have been suggested to represent trees. Scarcity of Fagaceae could be explained, in her opinion, by high fertility of the substrate and the presence of Carpinus. Teodoridis and Kvaček (2015) evaluated the plant assemblage of Matrý using the Integrated Plant Record (IRP) vegetation analysis (see Kovar-Eder et al. 2008, Teodoridis et al. 2011a, b), which predicted broad-leaved deciduous vegetation. This predicted zonal vegetation which is characterized by anomalously high percentage of broad-leaved deciduous components $(81 \%)$ in contrast to the other early late Oligocene assemblages studied. This fact, also indicated by palaeoclimatic proxies, verified a "riparian effect" (see Mach et al. 2014) as known from floras of Hlavačov Gravel and Sand (Teodoridis and Kvaček 2015). The above mentioned vegetation analysis carried out by Soukupová (2004) and Teodoridis and Kvaček (2015) is affected by a deficiency of studied taxa, i.e. 18 and 21. The new study presented here permits the use of 34 taxa and predicted quite different results which are more comparable with the results of IPR vegetation analysis from the late Oligocene of Central Europe (Teodoridis and Kvaček 2015). The latest results of IPR vegetation analysis for the Matrý plant assemblage shows the following ratio of key components, i.e. broad-leaved deciduous (BLD) $-70.5 \%$, broad-leaved evergreen (BLE) - $25.0 \%$, sclerophyllous + legume-like
$(\mathrm{SCL}+\mathrm{LEG})-4.6 \%$ and dry herbaceous + mesophytic herbaceous /zonal herbaceous/ (D-HERB + M-HERB / ZONAL HERB/) $-7.0 \%$. According to the thresholds for the key components (sensu Teodoridis et al. 2011b), the results predict a Mixed Mesophytic Forest vegetation type, which shows a closer affinity to other late Oligocene plant assemblages at Kleinsaubernitz, Počerny-Podlesí, Bockwitz and Borna-Ost which were mainly estimated as Broad-leaved Evergreen Forest (see Teodoridis and Kvaček 2015: tab. 3). Generally, the vegetation from Matrý can be characterized by a relatively high frequency of zonal elements and conifers. Similarly, as in Soukupová (2004), two specific vegetation assemblages can be distinguished based on the phytosociological approach. The vegetation assemblages differ in their plant compositions (depending on specific ecological conditions of the biotopes) and mutually integrate on their ecotons. The first vegetation assemblage is riparian vegetation preferring a waterlogged substrate. It includes mainly azonal elements such as Ulmus pyramidalis (E2-3), Platanus neptuni (E3), Craigia bronnii (E3), Betula dryadum/B. brongniartii (E3), Alnus cf. kefersteinii/A. rhenana (E3), Carpinus grandis (E3), ?Leguminosae gen. indet. (E3), Woodwardia muensteriana (E1), ?Sparganium sp. (E1) and ?Gramineae gen. et sp. indet. (E1). The second vegetation assemblage, limited to well-drained habitats, is a zonal mesophytic (mesic) assemblage characterized by the associated occurrence of the following conifers and angiosperms: Pinus cf. rigios (E3), Pinus cf. hepios (E3), Tetraclinis salicornioides (E2-3), Calocedrus suleticensis (E3), cf. Cephalotaxus parvifolia (E3), Torreya bilinica (E3), aff. Magnolia seifhennersdorfensis (E3), Liriodendron haueri (E3), Laurophyllum sp. (E3), Daphnogene cinnamomifolia (E3), ?Leguminosae gen. indet. (E3), Sloanea artocarpites (E3-4), Celtis pirskenbergensis (E3), Carya quadrangulal C. fragiliformis (E3-4), Cyclocarya sp. vel Carya sp. (E3), Alnus sp. (E3), Ostrya atlantidis (E3), Acer crenatifolium (E2-3), Acer cf. palaeosaccharinum (E3), Acer sp./ Acer integrilobum (E2-3), Pungiphyllum cf. cruciatum (E2-3), Dicotylophyllum spp. (E2-3) and Woodwardia muensteriana (E1). Teodoridis and Kvaček (2015: tab. 5) published palaeoclimatic estimates for Matrý derived from the Coexistence Approach (sensu Mosbrugger and Utescher 1997) which are as follows: mean annual temperature (MAT) $11.2-15.6{ }^{\circ} \mathrm{C}$, warmest month mean temperature (WMMT) $24.0-26.8{ }^{\circ} \mathrm{C}$, coldest month mean temperature (CMMT) $-1.6-5.0^{\circ} \mathrm{C}$ and mean annual precipitation (MAP) 879-1,355 mm. Similarly, palaeoclimatic proxies derived from Climate Leaf Multivariate Program (CLAMP sensu Wolfe and Spicer 1999) are MAT $13.6{ }^{\circ} \mathrm{C}$, WMMT $20.7{ }^{\circ} \mathrm{C}$ and CMMT $7.4{ }^{\circ} \mathrm{C}$. (Teodoridis and Kvaček 2015: tab. 4).

\section{Comparison with other plant assemblages in the České stř̌edohoří Mts., adjacent Saxony and the Doupovské hory Mts.}

Kvaček and Walther (in Akhmetiev et al. 2009: 79-84) attempted to characterize the position of the Matrý plant assemblage within the České středohoří Mts. They stressed the changing aspects of the flora, in which broad-leaved woody elements started to prevail. Representatives of the Betulaceae, 
Ulmaceae, Acer and Liriodendron constitute the majority of angiosperms, while more thermophilic plants, such as Lauraceae, Sloanea and Platanus neptuni are less common, some others, e.g. Engelhardia, are absent. Modernization of the flora of Matrý is apparent from the immigration of new elements, such as Woodwardia muensteriana, Pinus rigios, Ulmus pyramidalis and Acer crenatifolium.

The preliminary succession of the fossils plant assemblages in the České středohoří Mts., according to geological ages (Kvaček and Walther 2004), recognizes five vegetation levels starting with the Eocene, represented by the Doliostrobus flora and Oligocene floras with Juniperus, taxads, Calocedrus and Pinus. The Matrý flora falls into the upper levels in which Calocedrus is associated with Pinus. The Žichov flora (Schichow), although not yet fully revised (see Hably et al. 2001) represents the second site sharing both aspects and elements with Matrý. Such a trend corresponds with the recently obtained fish fauna data and the so far published syntheses (Kvaček and Teodoridis 2007).

Several connecting links can be recognized in the late Oligocene flora of Rhineland (Winterscheid and Kvaček 2014), where vegetation was apparently more thermophilic due to different palaeogeography. The coal-forming vegetation represented by Fagaceae and developed in the Oligocene and Miocene of the adjacent Sokolov Basin and the Doupovské hory Mts. left no traces in the České středohoří Mts.

\section{Acknowledgement}

We are thankful to both reviewers, Lilla Hably and Lutz Kunzmann, for their critical comments and suggestions. The study was undertaken as a part of the project PROGRES Q45 and Q17 carried out by Charles University, Faculty of Science and Faculty of Education, Prague.

\section{References}

Akhmetiev, M., Walther, H., Kvaček, Z. (2009): Mid-latitude Palaeogene floras of Eurasia bound to volcanic setting and palaeoclimatic events - experience obtained from the Far East Russia (Sikhote-Alin') and Central Europe (Bohemian Massif). - Acta Musei Nationalis Pragae, Series B - Historia Naturalis, 65(3-4): 61-121.

APG IV (2016): An update of the Angioperm Phylogeny Group classification for the orders and families of flowering plans: APG IC. - Botanical Journal of the Linnean Society, 181: 1-20. https://doi.org/10.1111/boj.12385

Brabenec, B. (1909): Souborná květena českého útvaru trretihorního [Comprehensive Flora of the Czech Tertiary] [part I]. - Archiv pro př́rodovědecké prozkoumání Čech, 14(3): 1-144. (in Czech)

Brown, R. W. (1935): Miocene leaves, fruits, and seeds from Idaho, Oregon, and Washington. - Journal of Paleontology, 9(7): 572-587.

Bůžek, Č. (1971): Tertiary flora from the northern part of the Pětipsy area (North-Bohemian Basin). - Rozpravy Ústředního ústavu geologického, 36(1): 1-118.

Bůžek, Č., Holý, F., Kvaček, Z. (1967): Eine bemerkenswerte Art der Familie Platanaceae Lindl. (1836) im nordböh- mischen Tertiär. - Monatsberichte der Deutschen Akademie der Wissenschaften, 9: 203-215.

Bůžek, Č., Holý, F., Kvaček, Z. (1976): Tertiary flora from the Volcanogenic Series at Markvartice and Veselíčko near Česká Kamenice (České Středohoří Mts.). - Sborník geologických věd, Paleontologie, 18: 69-132.

Cajz, V. (2000): Proposal of lithostratigraphy for the České středohoří Mts. volcanics. - Věstník Ústředního geologického ústavu, 75: 7-16.

Engelhardt, H. (1891): Ueber fossile Pflanzen aus tertiären Tuffen Nordböhmens. - Abhandlungen der Naturwissenschaftliche Gesellschaft Isis in Dresden, 3: 20-42.

Ettingshausen, C. v. (1866): Die fossile Flora des Tertiärbeckens von Bilin, I. - Denkschriften der Kaiserlichen Akademie der Wissenschaften, Mathematisch-naturwissenschaftliche Classe, 26: 1-98.

Ettingshausen, C. v. (1869): Die fossile Flora desTertiärbeckens von Bilin, III. - Denkschriften der Kaiserlichen Akademie der Wissenschaften, Mathematisch-naturwissenschaftliche Classe, 29: 1-110.

Frankenhäuser, H., Wilde, V. (1995): Stachelspitzige Blätter aus dem Mitteleozän von Eckfeld (Eifel). - Abhandlungen des Staatlichen Museums für Mineralogie und Geologie zu Dresden, 41: 97-115.

Göppert, H. R. (1836): De floribus in statu fossili commentatio. - Acta Physico-Medica Academiae Caesareae Leopoldino-Carolinae Naturae Curiosorum, 18: 547-572.

Göppert, H. R. (1855): Die tertiäre Flora von Schossnitz in Schlesien. - Heyn'sche Buchhandlung (E. Remer), Görlitz, $52 \mathrm{pp}$.

Hably, L., Erdei, B., Kvaček, Z. (2001): 19th century's palaeobotanical types and originals of the Hungarian Natural History Museum. - Hungarian Natural History Museum, Budapest, 235 pp.

Heer, O. (1855): Flora Tertiaria Helvetiae, I. - J. Wurster et comp., Winterthur, $117 \mathrm{pp}$.

Holý, F., Kvaček, Z., Teodoridis, V. (2012): A review of the early Miocene mastixioid flora of the Kristina Mine at Hrádek nad Nisou in North Bohemia (Czech Republic). - Acta Musei Nationalis Pragae, Series B - Historia Naturalis, 68 (3-4): 53-118.

Hurník, S. (1978): Die fossile Arten der Gattung Woodwardia Smith, 1793 und ihre Verbreitung im nordböhmischen Tertiär. - Acta Musei Nationalis Pragae, Series B - Historia Naturalis, 32(1976)(1): 15-46.

Jähnichen, H., Mai, D. H., Walther, H. (1980): Blätter und Früchte von Cercidiphyllum Siebold \& Zuccarini im mitteleuropäischen Tertiäre. - Schriftenreiften für geologische Wissenschaften, 16: 357-399.

Knobloch, E. (1961): Die oberoligozäne Flora des Pirskenberges bei Šluknov in Nord-Böhmen. - Sborník Ústředního ústavu geologického, 26: 241-315.

Kovar-Eder, J., Jechorek, H., Kvaček, Z., Parashiv, V. (2008): The Integrated Plant Record: an essential tool for reconstructing Neogene zonal vegetation in Europe. Palaios, 23: 97-111.

Kovar-Eder, J., Kvaček, Z., Ströbitzer-Hermann, M. (2004): The Miocene Flora of Parschlug (Styria, Austria) - Revision and Synthesis. - Annalen des Naturhistorischen Museums in Wien, Serie A, 105: 45- 159. https://doi.org/10.2110/palo.2006.p06-039r 
Kräusel, R. (1921): Nachträge zur Tertiärflora Schlesiens. III. - Jahrbuch der Preussischen Geologischen Landesanstalt zu Berlin für das Jahr 1919, 40(3): 363-433.

Kvaček, J., Straková, M. (1997): Catalogue of fossil plants described in works of Kaspar M. Sternberg. - National Museum, Prague, 201 pp.

Kvaček, Z. (1984): Tertiary taxads of NW Bohemia. - Acta Universitatis Carolinae, Geologica, 4(1982): 471-491.

Kvaček, Z. (1989): Fosilní Tetraclinis Mast. (Cupressaceae) [Fossil Tetraclinis Mast. (Cupressaceae)]. - Časopis Národního muzea, řada prírodovědecká, 155: 45-54. (in Czech)

Kvaček, Z. (1999): An ancient Calocedrus (Cupressaceae) from the European Tertiary. - Flora, 194: 237-248. https://doi.org/10.1016/S0367-2530(17)30902-7

Kvaček, Z. (2002): Late Eocene landscape, ecosystems and climate in north Bohemia with particular reference to the locality Kučlín near Bílina. - Bulletin of the Czech Geological Survey, 77: 217-236.

Kvaček, Z., Bůžek, Č., Manchester, S. R. (1991): Fossil fruits of Pteleaecarpum Weyland - Tiliaceous, not Sapindaceous. - Botanical Gazette, 152: 522-523. https://doi.org/10.1007/s00606-003-0082-2

Kvaček, Z., Dvořák, Z., Mach, Sakala, J. (2004): Třetihorní rostliny severočeské hnědouhelné pánve [Tertiary plants of North-Bohemian Brown-coal Basin]. - Severočeské doly, a.s., Chomutov, Granit, Praha, 160 pp. (in Czech)

Kvaček, Z., Hably, L., Manchester, S. R. (2001): Sloanea (Elaeocarpaceae) fruits and foliage from the Early Oligocene of Hungary and Slovenia. - Palaeontographica, Abteilung B, 259(1-6): 113-124.

Kvaček, Z., Hurník, S. (2000): Revision of Early Miocene plants preserved in baked rocks in the North Bohemian Tertiary. - Acta Musei Nationalis Pragae, Series B - Historia Naturalis, 56(1-2): 1-48.

Kvaček, Z., Konzalová, M. (1996): Emended characteristics of Cercidiphyllum crenatum (Unger) R. W. Brown based on reproductive structures and pollen in situ. - Palaeontographica, Abteilung B, 239: 147-155.

Kvaček, Z., Manchester, S. R. (2004): Vegetative and reproductive structure of the extinct Platanus neptuni from the Tertiary of Europe and relationships within the Platanaceae. - Plant Systematics and Evolution, 244: 1-29. https://doi.org/10.1007/s00606-003-0082-2

Kvaček, Z., Teodoridis, V. (2007): Tertiary macrofloras of the Bohemian Massif: a review with correlations within Boreal and Central Europe. - Bulletin of Geosciences, 82(4): 409-418.

https://doi.org/10.3140/bull.geosci.2007.04.383

Kvaček, Z., Teodoridis, V. (2011): A Late Eocene flora of Kučlín near Bílina in North Bohemia revisited. - Acta Musei Nationalis Pragae, Series B - Historia Naturalis, 67(3-4): 77-82.

Kvaček, Z., Walther, H. (1981): Studium über “Quercus cruciata" und analoge Blattformen aus dem Tertiär Europas. - Acta Palaeobotanica, 21(2): 77-100.

Kvaček, Z., Walther, H. (1995): The Oligocene volcanic flora of Suletice-Berand near Ústí nad Labem, North Bohemia - a review. - Acta Musei Nationalis Pragae, Series B - Historia Naturalis, 50(1-4): 25-54.

Kvaček, Z., Walther, H. (1998): The Oligocene volcanic flora of Kundratice near Litoměřice, České středohoří
Volcanic complex (Czech Republic). - Acta Musei Nationalis Pragae, Series B - Historia Naturalis, 54: 1-43.

Kvaček, Z., Walther, H. (2004): Oligocene flora of Bechlejovice at Děčín from the neovolcanic area of the České Středohoři Mountains, Czech Republic. - Acta Musei Nationalis Pragae, Series B - Historia Naturalis, 60: 9-60.

Mach, K., Teodoridis, V., Matys Grygar, T., Kvaček, Z., Suhr, P., Standke, G. (2014): An evaluation of palaeogeography and palaeoecology in the Most Basin (Czech Republic) and Saxony (Germany) from the late Oligocene to the early Miocene. - Neues Jahrbuch für Geologie und Paläontologie, Abhandlungen, 272(1): 13-45. https://doi.org/10.1127/0077-7749/2014/0395

Mai, D. H. (1981): Der Formenkreis der Vietnam-Nuß Carya poilanei (Chev.) Leroy in Europa. - Feddes Repertorium, 92: 339-385.

https://doi.org/10.1002/fedr.19810920502

Mai, D. H. (1999): Die untermiozänen Floren aus der Spremberger Folge und dem 2. Flözhorizont in der Lausitz, Teil I: Farnpflazen, Koniferen und Monocotyledonen. - Palaeontographica, Abteilung B, 250: 1-76.

Mai, D. H. (2007): The floral change in the Tertiary of the Rhön mountains (Germany). - Acta Palaeobotanica, 47(1): 135-143.

Mai, D. H., Walther, H. (1978): Die Floren der Haselbacher Serie im Weisselster - Becken (Bezirk, Leipzig, DDR). - Abhandlungen des Staatlichen Museums für Mineralogie und Geologie zu Dresden, 28: 1-101.

Menzel, P. (1901): Die Gymnospermen der nordböhmischen Braunkohlenformation. - Abhandlungen der Naturwissenschaftlichen Gesellschaft ISIS zu Dresden, 1900(2): 49-69, 85-110.

Mosbrugger, V., Utescher, T. (1997): The coexistence approach - a method for quantitative reconstructions of Tertiary terrestrial palaeoclimate data using plant fossils. - Palaeogeography, Palaeoclimatology, Palaeoecology, 134: 61-86. https://doi.org/10.1016/S0031-0182(96)00154-X

Procházka, M., Bůžek, Č. (1975): Maple leaves from the Tertiary of North Bohemia. - Rozpravy Ústředního ústavu geologického, 41: 1-86.

Radon̆, M. (2001): Výzkum terciérních paleontologických lokalit v Českém středohoří [Studies on Tertiary palaeontological localities in the České středohoří Mts.]; Závěrečná zpráva programového projektu Ministerstva kultury České republiky [Final Report of the Program Project of the Ministry of Culture, the Czech Republic]. - MS, Regionální muzeum v Teplicích, Teplice, 380 pp. (copy in private library of Miroslav Radoň)

Radoň, M. (2002): Současné nálezy flóry a fauny na některých známých a nových palaeontologických lokalitách terciéru ve střední a západní části Českého středohoří [New finds of fossil flora and fauna from several known and new Tertiary localities from central and western part of České středohoří Mts.]. - Zprávy a studie Regionáního muzea v Teplicích, 24: 113-187. (in Czech)

Radoň, M. (2014): Nový nález fosilní včely z terciéru Českého středohoři [New find of fossil bee from the Tertiary of the České středohoří Mts.]. - Zprávy a studie Regionálního muzea v Teplicích, 30: 147-153. (in Czech) 
Radoň, M., Kvaček, Z., Walther, H. (2006): Oligocene megafossil plant remains and environment from the newly recovered locality of the Holý Kluk hill near Proboštov (České středohoří Mountains, Czech Republic). - Acta Universitatis Carolinae, Geologica, 47: 95-124.

Řeháková, Z. (1967): Výsledky mikropaleontologického výzkunu diatomite [Results of the micropalaeontological research of diatomite]. Základní geologická mapa 1 : 25 000, list M-33-53-A Ústí nad Labem. - MS, Archiv Geofond (no. P 19929/12-14, 28-35), Česká geologická slaužby, Prague, the Czech Republic. (copy in Geofond archive, Czech Geological Survey)

Saporta, G. (1891): Végétation du niveau aquitanien de Manosque. - Mémoires de la société géologique de France, Paléontologie, 9: 1-83.

Saporta, G., Marion, A. F. (1876): Recherches sur les végétaux fossiles de Meximieux. - Archives du Museum d'Histoire Naturelle de Lyon, 1: 131-335.

Sedláčková, L. (2004): Faciální vývoj vulkanosedimentárních komplexů v okolí Ústí nad Labem a Děčína (České středohoří) [Facies development of volcano-sedimentary complexes near Ústí nad Labem and Děčín (České stř́edohoří Mts.)]; Diplomová práce [MSc thesis]. - MS, Ústav geologie a paleontologie, Př́rodovědecká fakulta, Univerzita Karlova [Institute of Geology and Palaeontology, Faculty of Science, Charles University], Prague, the Czech Republic, 94 pp. (in Czech) (copy in library of the Institute of Geology and Palaeontology, Faculty of Science, Charles University)

Soukupová, H. (2004): Vegetace a paleoekologie vybraných lokalit Českého středohoří [Vegetation and palaeoenvironment of selected localities in the České středohoří Mts.]; Diplomová práce [MSc thesis]. - MS, Ústav geologie a paleontologie, Př́rodovědecká fakulta, Univerzita Karlova [Institute of Geology and Palaeontology, Faculty of Science, Charles University], Prague, the Czech Republic, 105 pp. (in Czech) (copy in library of the Institute of Geology and Palaeontology, Faculty of Science, Charles University)

Sternberg, K. M. (1820-1838): Versuch einer geognostischbotanischen Darstellung der Flora der Vorwelt. vol. I, 1(1820) 24 pp., pls 1-13, in Commission im Deutschen Museum, F. Fleischer, Leipzig, vol. I, 2 (1821) 33 pp., pls. 14-26, in Commission im Deutschen Museum, F. Fleischer, Leipzig, vol. I, 3 (1823) 39 pp., pls 27-39, Ernst Brenck's Wittwe, Regensburg, vol. I, 4 (1825) 48 pp. tent. I-XLII, pls 40-59, Ernst Brenck's Wittwe, Regensburg, vol. II, 5/6 (1833) 80 pp., pls 1-26, Johann Spurny, Prague, vol. II, 7/8 (C. B. Presl and A. J. Corda coauthors): 81-220, pls 27-68A, B, Gotlieb Haase Söhne, Prag.

Stizenberger, E. (1851): Uebersicht der Versteinerungen des Grossherzogthums Baden. - Verlag der UniversitätsBuchhandlung von J. Diernfellner, Freiburg i./B., 144 pp.
Stur, D. (1867): Beiträge zur Kenntnis der Flora der Süßwasserquarzite, der Congerien- und Cerithienschichten im Wiener und ungarischen Becken. - Jahrbuch der Geologischen Reichsanstalt, 17(1): 77-188.

Teodoridis, V., Kovar-Eder, J., Marek, P., Kvaček, Z., Mazouch, P. (2011a): The Integrated Plant Record Vegetation Analysis: Internet Platform and Online Application. - Acta Musei Nationalis Pragae, Series B - Historia Naturalis, 67(3-4): 159-164.

Teodoridis, V., Kovar-Eder, J., Mazouch, P. (2011b): The IPR-vegetation analysis applied to modern vegetation in SE China and Japan. - PALAIOS, 26(10): 623-638. https://doi.org/10.2110/palo.2010.p10-149r

Teodoridis, V., Kvaček, Z. (2015): Palaeoenvironmental evaluation of Cainozoic plant assemblages from the Bohemian Massif (Czech Republic) and adjacent Germany. - Bulletin of Geosciences, 90(3): 695-720. https://doi.org/10.3140/bull.geosci.1553

Unger, F. (1841-47): Chloris protogaea. 1-10. - W. Engelmann, Leipzig, 149 pp.

Unger, F. (1850): Genera et species plantarum fossilium. W. Braunmüller, Vindobonae, XL + 627 pp.

Unger, F. (1852): Iconographia plantarum fossilium. Denkschriften der Kaiserlichen Akademie der Wissenschaften, Mathematisch-naturwissenschaftliche Classe, 4: 73-118.

Walther, H. (1964): Paläobotanische Untersuchungen im Tertiär von Seifhennersdorf. - Jahrbuch des Staatlichen Museums für Mineralogie und Geologie zu Dresden, 1964: 1-131.

Walther, H. (1972): Studien über tertiäre Acer Mitteleuropas. - Abhandlungen des Staatlichen Museums für Mineralogie und Geologie zu Dresden, 19: 1-309.

Walther, H., Kvaček, Z. (2007): Early Oligocene flora of Seifhennersdorf (Saxony). - Acta Musei Nationalis Pragae, Series B - Historia Naturalis, 63(2-4): 85-174.

Weber, C. O. (1852): Die Tertiärflora der niederrheinischen Braunkohlenformation. - Palaeontographica, 2: 115282.

Wessel, Ph., Weber, O. (1856): Neuer Beitrag zur TertiärFlora der niederrheinischen Braunkohlenformation. Palaeontographica, 4: 1-57.

Weyland, H. (1948): Beiträge zur Kenntnis der rheinischen Tertiärflora. VII. - Palaeontographica, Abteilung B, 88: 115-188.

Winterscheid, H., Kvaček, Z. (2014): Revision der Flora aus den oberoligozänen Seeablagerungen von Orsberg bei Unkel am Rhein (Rheinland-Pfalz, Deutschland). - Palaeontographica, Abteilung B, 291(1-3): 1-83.

Wolfe, J. A., Spicer, R. A. (1999): Fossil Leaf Character States: Multivariate Analysis. - In: Jones, T. P., Rowe, N. P. (eds), Fossil Plants and Spores: Modern Techniques. Geological Society, London, pp. 233-239. 


\section{Explanations of plates}

\section{PLATE 1}

1. Woodwardia muensteriana (C.PreSL in STERnB.) KRÄUSEL. Fragment of pinna, PA 1428.1, scale bar $5 \mathrm{~mm}$.

2. Woodwardia muensteriana (C.PRESL in STERnB.) KRÄUSEL. Detail of venation, PA 1428.1, scale bar 5 mm.

3. Pinus hepios (Unger) Heer. Binate needle fascicle, PA 1188.1 , scale bar $10 \mathrm{~mm}$.

4. Pinus hepios (Unger) Heer. Binate needle fascicle, PA 1382, scale bar $10 \mathrm{~mm}$.

5. Pinus rigios (Unger) Ettingsh. Ternate needle fascicle, PA 1159.2, scale bar $10 \mathrm{~mm}$.

6. Pinus rigios (Unger) Ettingsh. Ternate needle fascicle, PA 1348, scale bar $10 \mathrm{~mm}$.

7. Cephalotaxus parvifolia (H.WALther) KvačEK et H.WALthER. Needle leaf, PA 1393, scale bar $5 \mathrm{~mm}$.

8. Torreya bilinica SAPORTA et MARION. Needle leaf, PA 1358, scale bar $5 \mathrm{~mm}$.

9. Torreya bilinica SAPORTA et MARION. Needle leaf, PA 1584, scale bar $5 \mathrm{~mm}$.

10. Tetralinis salicornioides (Unger) KVAČEK. Seed, PA 1177, scale bar $5 \mathrm{~mm}$.

11. Tetralinis salicornioides (UNGER) KVAČEK. Leaf segment, PA 1427, scale bar $5 \mathrm{~mm}$.

12. Calocedrus suleticensis (BRABENEC) KVAČEK. Seed cone with fragmentary stalk, PA 1173.1, scale bar $10 \mathrm{~mm}$.

13. Calocedrus suleticensis (BRABEnec) KvaČEK. Detail of seed cone, PA 1173.1, scale bar $5 \mathrm{~mm}$.

\section{PLATE 2}

1. ?Magnolia seifhennersdorfensis H.WALTHER et KVAČEK. Incomplete leaf, PA 1448, scale bar $10 \mathrm{~mm}$.

2. ? Magnolia seifhennersdorfensis H.WALTHER et KVAČEK. Apical part of leaf, PA 1195.3, scale bar $10 \mathrm{~mm}$.

3. ? Magnolia seifhennersdorfensis H.WALTHER et KVAČEK. Basal part with fragmentary petiole, PA 1367, scale bar $10 \mathrm{~mm}$.

4. Liriodendron haueri ETTINGSH. Incomplete bilobate leaf, PA 1187, scale bar $10 \mathrm{~mm}$.

5. Liriodendron haueri ETTINGSH. Incomplete bilobate leaf, PA 1399, scale bar $10 \mathrm{~mm}$.

6. Liriodendron haueri EtTingsh. Complete bilobate leaf, PA 1440.1, scale bar $10 \mathrm{~mm}$.

7. Liriodendron haueri EtTINGSH. Winged samara, PA 1359.1, scale bar $5 \mathrm{~mm}$.

8. Liriodendron haueri EtTINGSH. Winged samara, PA 1426.1, scale bar $5 \mathrm{~mm}$.

\section{PLATE 3}

1. Laurophyllum sp. Complete leaf with petiole, PA 1398, scale bar $10 \mathrm{~mm}$.

2. Laurophyllum sp. Incomplete leaf with petiole, PA 1158.6, scale bar $10 \mathrm{~mm}$.

3. Laurophyllum sp. Incomplete leaf, PA 1158.8, scale bar $10 \mathrm{~mm}$.

4. Laurophyllum sp. Complete leaf with petiole, PA 1383.1, scale bar $10 \mathrm{~mm}$.
5. Laurophyllum sp. Incomplete leaf, PA 1182.3, scale bar $10 \mathrm{~mm}$.

6. Laurophyllum sp. Incomplete leaf, PA 1189.4, scale bar $10 \mathrm{~mm}$.

7. Laurophyllum sp. Incomplete apical part of leaf, PA 1584, scale bar $10 \mathrm{~mm}$.

\section{PLATE 4}

1. Daphnogene cinnamomifolia (BRONGN.) UNGER forma lanceolata (UNGER) KVAČEK et H.WALTHER. Incomplete leaf with petiole, PA 1153.2, scale bar $10 \mathrm{~mm}$.

2. Daphnogene cinnamomifolia (BRONGN.) UNGER forma lanceolata (UNGER) KVAČEK et H.WALTHER. Incomplete leaf with petiole, PA 1153.1, scale bar $10 \mathrm{~mm}$.

3. Daphnogene cinnamomifolia (BRONGN.) UNGER forma lanceolata (Unger) KVAČEK et H.WALther. Incomplete leaf with petiole, PA 1346, scale bar $10 \mathrm{~mm}$.

4. Daphnogene cinnamomifolia (BRONGN.) UNGER forma lanceolata (UNGER) KVAČEK et H.WALTHER Incomplete leaf with petiole, PA 1350, scale bar $10 \mathrm{~mm}$.

5. ? Sparganium sp. Leaf fragment with parallel venation, PA 1424.1, scale bar $10 \mathrm{~mm}$.

6. ? Gramineae gen. et sp. indet. Parallel-veined grass-like leaf fragment, PA 1168.1, scale bar $10 \mathrm{~mm}$.

7. Platanus neptuni (EtTingsh.) BưžEK, Holý et KvačEK. Group of incomplete leaflets possibly from a compound leaf, PA 1362, scale bar $10 \mathrm{~mm}$.

8. Platanus neptuni (EtTingsh.) BůŽEK, HolÝ et KvAČEK. Strap-like stipule, PA 1179.1, scale bar 5 mm.

9. Platanus neptuni (EtTingsh.) BůŽEK, HolÝ et KvaČeK. Globular infructescence, PA 1435, scale bar $5 \mathrm{~mm}$.

10. Platanus neptuni (Ettingsh.) BưŽEK, Holý et KvačEK. Complete leaf with long petiole, PA 1157.4, scale bar $10 \mathrm{~mm}$.

\section{PLATE 5}

1. Cercidiphyllum crenatum (UnGer) R.W.BR. Almost complete leaf, PA 1581, scale bar $5 \mathrm{~mm}$.

2. ? Leguminosae gen. indet. Isolated leaflet with short fragmentary petiolule, PA 1391, scale bar $10 \mathrm{~mm}$.

3. ? Leguminosae gen. indet. Isolated leaflet with short fragmentary petiolule, PA 1411.1, scale bar $10 \mathrm{~mm}$.

4. ? Leguminosae gen. indet. Isolated leaflet with short fragmentary petiolule, PA 1405.1, scale bar $10 \mathrm{~mm}$.

5. Sloanea artocarpites (EtTingsh.) KvaČEK et HABly. Incomplete leaf, PA 1410.1, scale bar $10 \mathrm{~mm}$.

6. Ulmus pyramidalis GöPP. Two complete attached leaves, PA 1191.1, scale bar $10 \mathrm{~mm}$.

7. Ulmus pyramidalis GöPP. Complete leaf with fragmentary petiole, PA 1429, scale bar $10 \mathrm{~mm}$.

8. Ulmus pyramidalis GöPr. Incomplete leaf, PA 1162.2, scale bar $10 \mathrm{~mm}$.

9. Celtis pirskenbergensis (ERW.KNOBLOCH) KVAČEK et H.WALTHER. Incomplete leaf, PA 1353, scale bar $10 \mathrm{~mm}$.

10. Celtis pirskenbergensis(ERW.KNOBLOCH) KVAČEK et H.WALTHER. Detail of leaf bases, PA 1353, scale bar $5 \mathrm{~mm}$. 


\section{PLATE 6}

1. Carya fragiliformis (Sternb.) KVAČEK et H.WALther. Complete leaflet, PA 1418, scale bar $10 \mathrm{~mm}$.

2. Carya fragiliformis (Sternb.) KvaČEK et H.Walther. Complete leaflet, PA 1340, scale bar $10 \mathrm{~mm}$.

3. Carya fragiliformis (Sternb.) KVAČEK et H.WAlther. Complete leaflet, PA 1351, scale bar $10 \mathrm{~mm}$.

4. Carya quadrangula (KIRCHH.) J.-F.LeROY. Incomplete fruit, PA 1365, scale bar $10 \mathrm{~mm}$.

5. Carya quadrangula (KirchH.) J.-F.Leroy. Complete fruit, PA 1164.1, scale bar $10 \mathrm{~mm}$.

6. Carya quadrangula (КIRCHH.) J.-F.Leroy. Incomplete half of fruit, PA 1580, scale bar $5 \mathrm{~mm}$.

7. Cyclocarya sp. vel Carya sp. Incomplete leaflet with denticulate margin, PA 1170.1, scale bar $10 \mathrm{~mm}$.

8. Cyclocarya sp. vel Carya sp. Incomplete leaflet with denticulate margin, PA 1170.7, scale bar $10 \mathrm{~mm}$.

9. Cyclocarya sp. vel Carya sp. Incomplete leaflet with denticulate margin, PA 1170.8, scale bar $10 \mathrm{~mm}$.

\section{PLATE 7}

1. Betula brongniartii EtTingSh. Incomplete leaf with double sharply serrate margin, PA 1152.1 , scale bar $10 \mathrm{~mm}$.

2. Betula brongniartii EtTINGSH. Incomplete leaf with double sharply serrate margin and short petiole, PA 1152.2, scale bar $10 \mathrm{~mm}$.

3. Betula brongniartii EtTingsh. Incomplete leaf with double sharply serrate margin and short petiole, PA 1582, scale bar $10 \mathrm{~mm}$.

4. Betula brongniartii EtTingsh. Almost complete leaf with double sharply serrate margin and shortly attenuate apex, PA 1342, scale bar $10 \mathrm{~mm}$.

5. Betula dryadum Brongn. Double-winged fruitlet PA 1420.1, scale bar $5 \mathrm{~mm}$.

6. Betula dryadum BRONGn. Bract, PA 1446, scale bar $5 \mathrm{~mm}$.

7. Alnus rhenana (P.WeSsel et C.O.WeBer) WinTERsCheid et KVAČEK. Basal leaf part with finely widely serrate margin and fragmentary petiole, PA 1375 , scale bar $10 \mathrm{~mm}$.

8. Alnus rhenana (P.Wessel et C.O.Weber) WinTERSCHEID et KVAČEK. Incomplete leaves with finely widely serrate margin and fragmentary petiole, PA 1380, scale bar $10 \mathrm{~mm}$.

9. Alnus rhenana (P.Wessel et C.O.WeBer) WinTERSCHeid et KVAČEK. Incomplete apical leaf part with finely widely serrate margin, PA 1343, scale bar $10 \mathrm{~mm}$.

10. Alnus cf.kefersteinii (GöPp.) UnGER. Two infructescenses, PA 1576, scale bar $10 \mathrm{~mm}$.

\section{PLATE 8}

1. Alnus sp. Almost complete leaf with fine denticulate margin and petiole, PA 1579.1, scale bar $5 \mathrm{~mm}$.

2. Alnus sp. Almost complete leaf with fine denticulate margin and petiole, PA 1172.4, scale bar $10 \mathrm{~mm}$.

3. Alnus sp. Almost complete leaf with fine denticulate margin and petiole, PA 1578, scale bar $10 \mathrm{~mm}$.

4. Carpinus grandis Unger. Almost complete leaf with fine serrate-dentate margin, PA 1574, scale bar $10 \mathrm{~mm}$.

5. Carpinus grandis UnGER. Almost complete leaf with fine serrate-dentate margin, PA 1388, scale bar $10 \mathrm{~mm}$.
6. Carpinus grandis Unger. Almost complete leaf with fine serrate-dentate margin, PA 1344, scale bar $10 \mathrm{~mm}$.

7. Ostrya atlantidis Unger. Parallel-veined involucre, PA 1583, scale bar $5 \mathrm{~mm}$.

8. Ostrya atlantidis UnGER. Leaf with mucronately serrate margin and petiole, PA 1441, scale bar $5 \mathrm{~mm}$.

9. Ostrya atlantidis UNGER. Leaf with mucronately serrate margin and petiole, PA 1163.5, scale bar $10 \mathrm{~mm}$.

10. Ostrya atlantidis UNGER. Leaf with mucronately serrate margin and petiole, PA 1577, scale bar $5 \mathrm{~mm}$.

\section{PLATE 9}

1. Acer crenatifolium Ettingsh. Trilobate leaf fragments with crenate margin, PA 1186.2, scale bar $10 \mathrm{~mm}$.

2. Acer crenatifolium EtTingsh. Incomplete trilobate leaf with crenate margin PA 1361.1, scale bar $10 \mathrm{~mm}$.

3. Acer cf. palaeosaccharinum STUR. Complete tricuspidate leaf with widely simple to irregularly double dentate margin, PA 1356, scale bar $10 \mathrm{~mm}$.

4. Acer cf. palaeosaccharinum STUR. Incomplete tricuspidate leaf with widely simple to irregularly double dentate margin, PA 1189.1, scale bar $10 \mathrm{~mm}$.

5. Acer sp. Fruit, PA 1575, scale bar $5 \mathrm{~mm}$.

6. Acer cf. palaeosaccharinum STUR. Incomplete tricuspidate leaf with widely simple to irregularly double dentate margin, PA 1184.1, scale bar $10 \mathrm{~mm}$.

7. Acer sp. Isolated mericarp, PA 1416, scale bar $5 \mathrm{~mm}$.

8. Acer integrilobum C.O.WEBER. Incomplete trilobate leaf with entire margin, PA 1449, scale bar $10 \mathrm{~mm}$.

\section{PLATE 10}

1. Dicotylophyllum sp. 3. Incomplete widely lanceolate leaf with coarsely serrate margin, PA 1169.1, scale bar $10 \mathrm{~mm}$.

2. Pungiphyllum cf. cruciatum (A.BrAUn) FrankenHÄUSER et V.WILDE. Complete leaf with widely dentate margin on its apical part, PA 1340, scale bar $10 \mathrm{~mm}$.

3. Dicotylophyllum sp. 1. Incomplete widely elliptic leaf with entire margin and long petiole, PA 1188.1, scale bar $10 \mathrm{~mm}$.

4. Dicotylophyllum sp. 1. Almost complete elliptic leaf with entire margin and long petiole, PA 1412.2, scale bar $10 \mathrm{~mm}$.

5. Craigia bronnii (Unger) KvaČEK, BƯŽEK et MANChester. Fruit capsule, PA 1360, scale bar $5 \mathrm{~mm}$.

6. Craigia bronnii (UNGer) KVAČEK, BƯŽEK et MANCHESTER. Fruit capsule, PA 1156.2, scale bar $5 \mathrm{~mm}$.

7. Dicotylophyllum sp. 2. Complete leaf with narrow cuneate base and sharply densely dentate margin, PA 1363.2, scale bar $10 \mathrm{~mm}$.

8. Dicotylophyllum sp. 2. Basal part of leaf with sharply and densely dentate margin, PA 1425.1, scale bar $10 \mathrm{~mm}$.

9. Dicotylophyllum sp. 3. Complete ovate leaf with coarsely serrate margin and short petiole, PA 1431, scale bar $10 \mathrm{~mm}$.

10. Dicotylophyllum sp. 4. Complete obovate leaf with bluntly acute apex and entire margin, PA 1585.1, scale bar $10 \mathrm{~mm}$.

11. Dicotylophyllum sp. 4. Incomplete obovate leaf with bluntly acute apex, cuneate base and entire margin, PA 1430, scale bar $10 \mathrm{~mm}$. 
PLATE 1
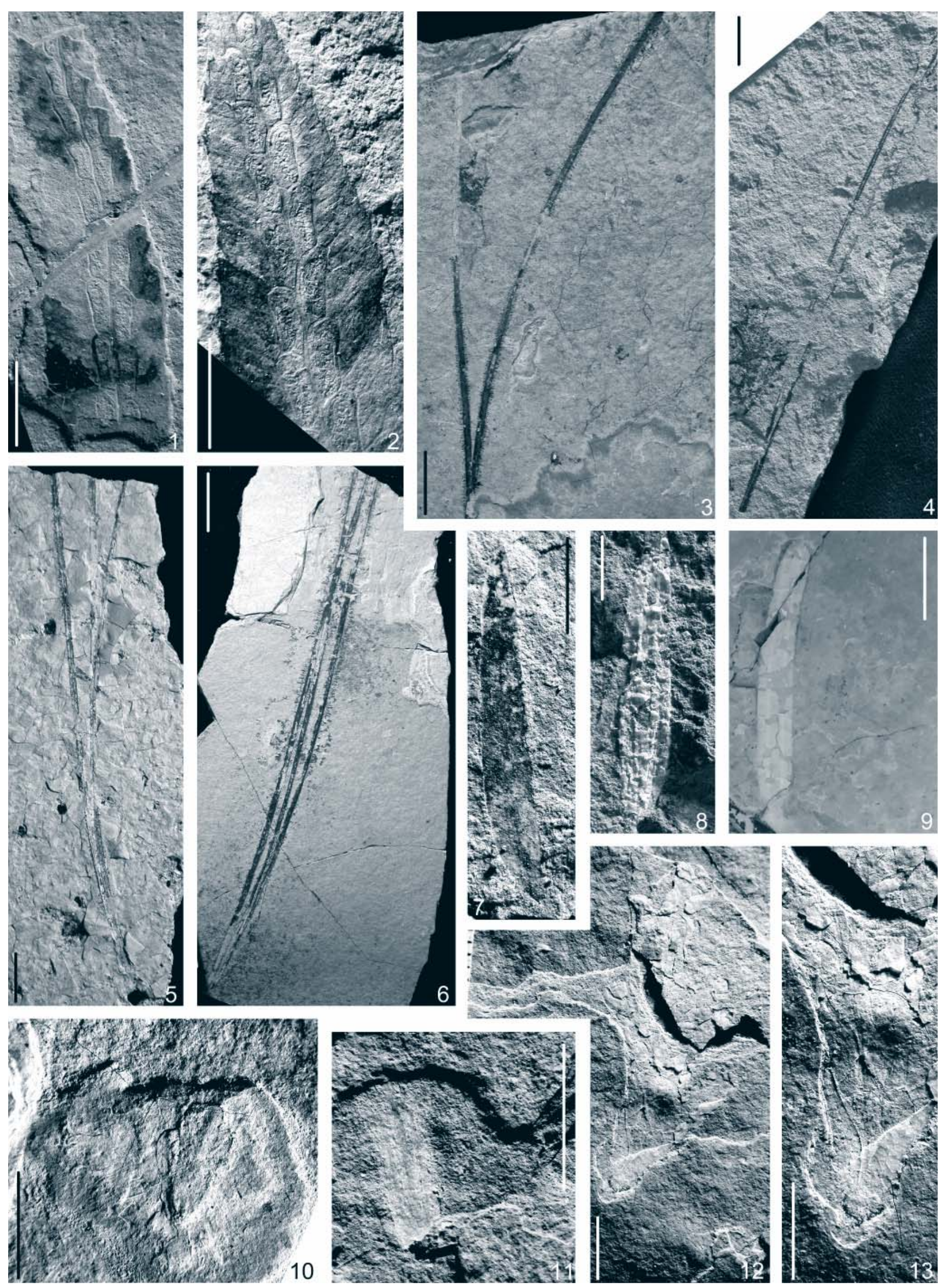

Lit

New is

2 t

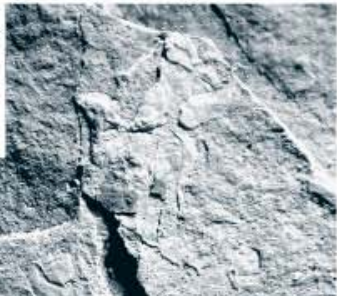

6
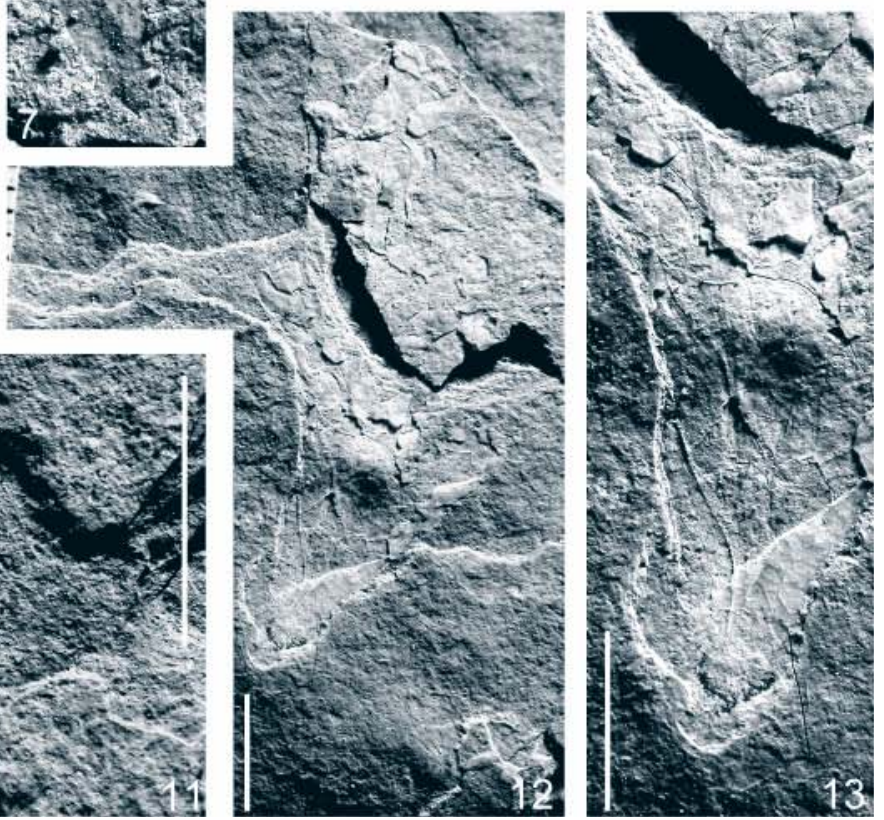
PLATE 2
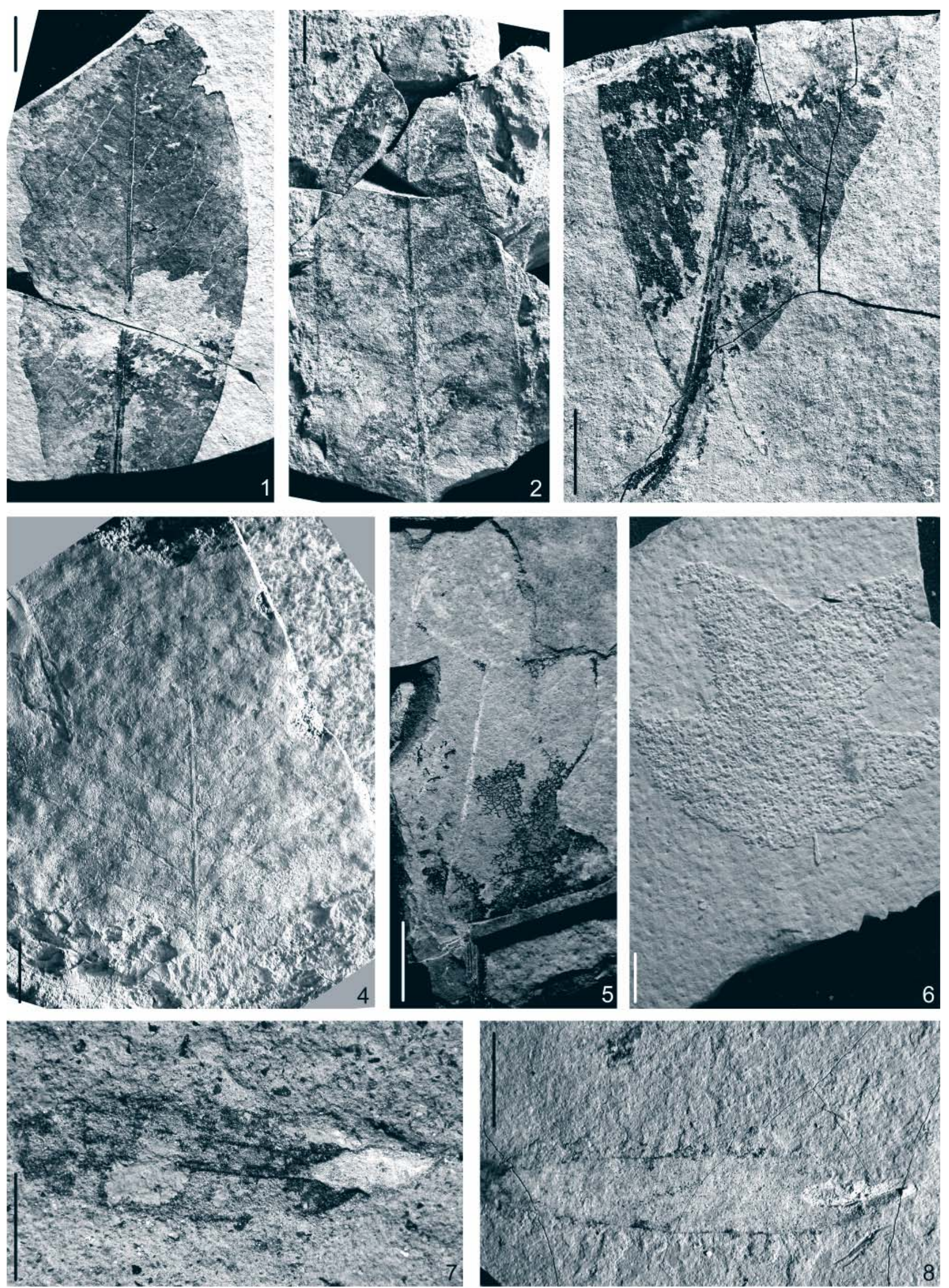
PLATE 3
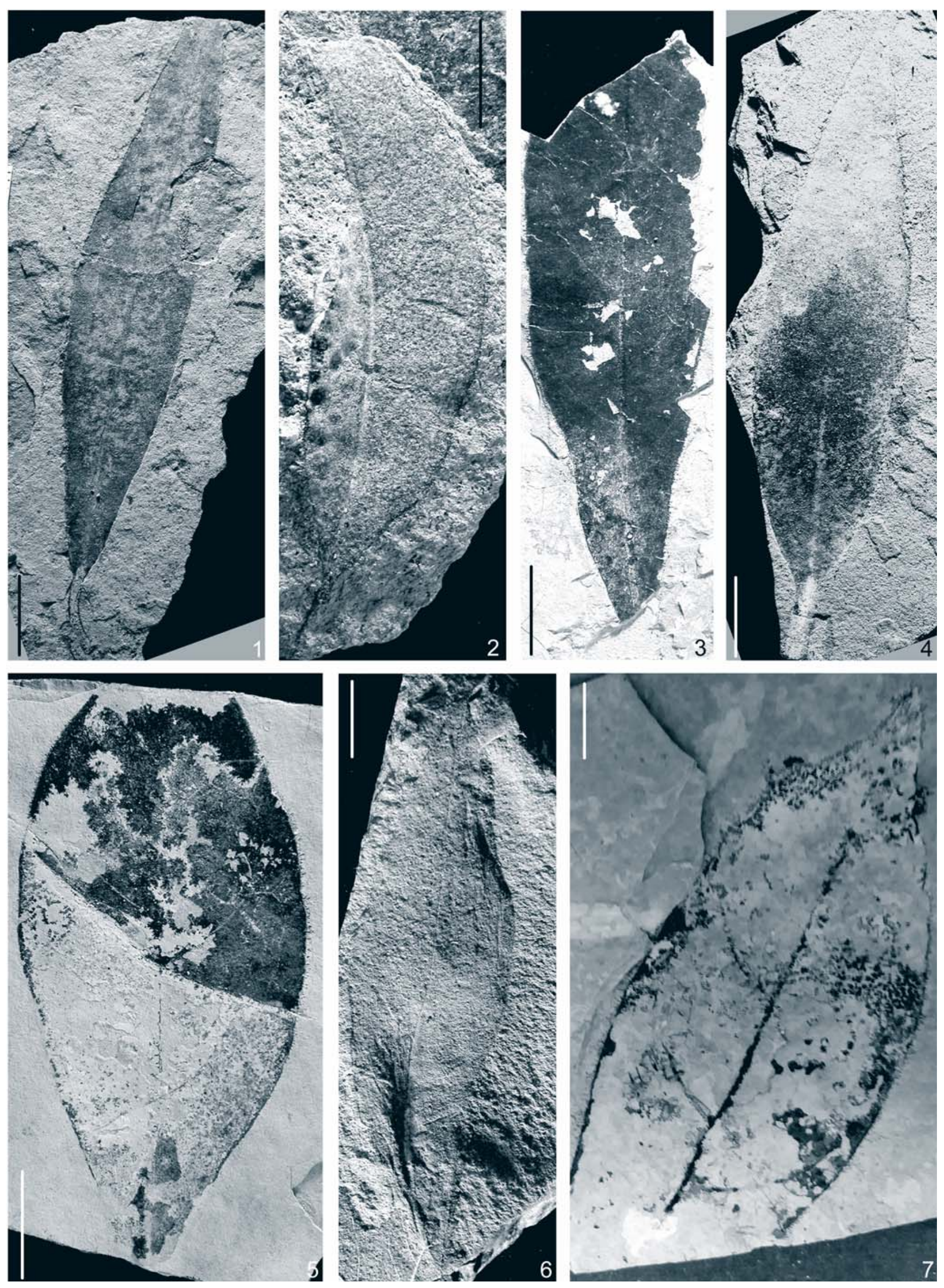


\section{PLATE 4}
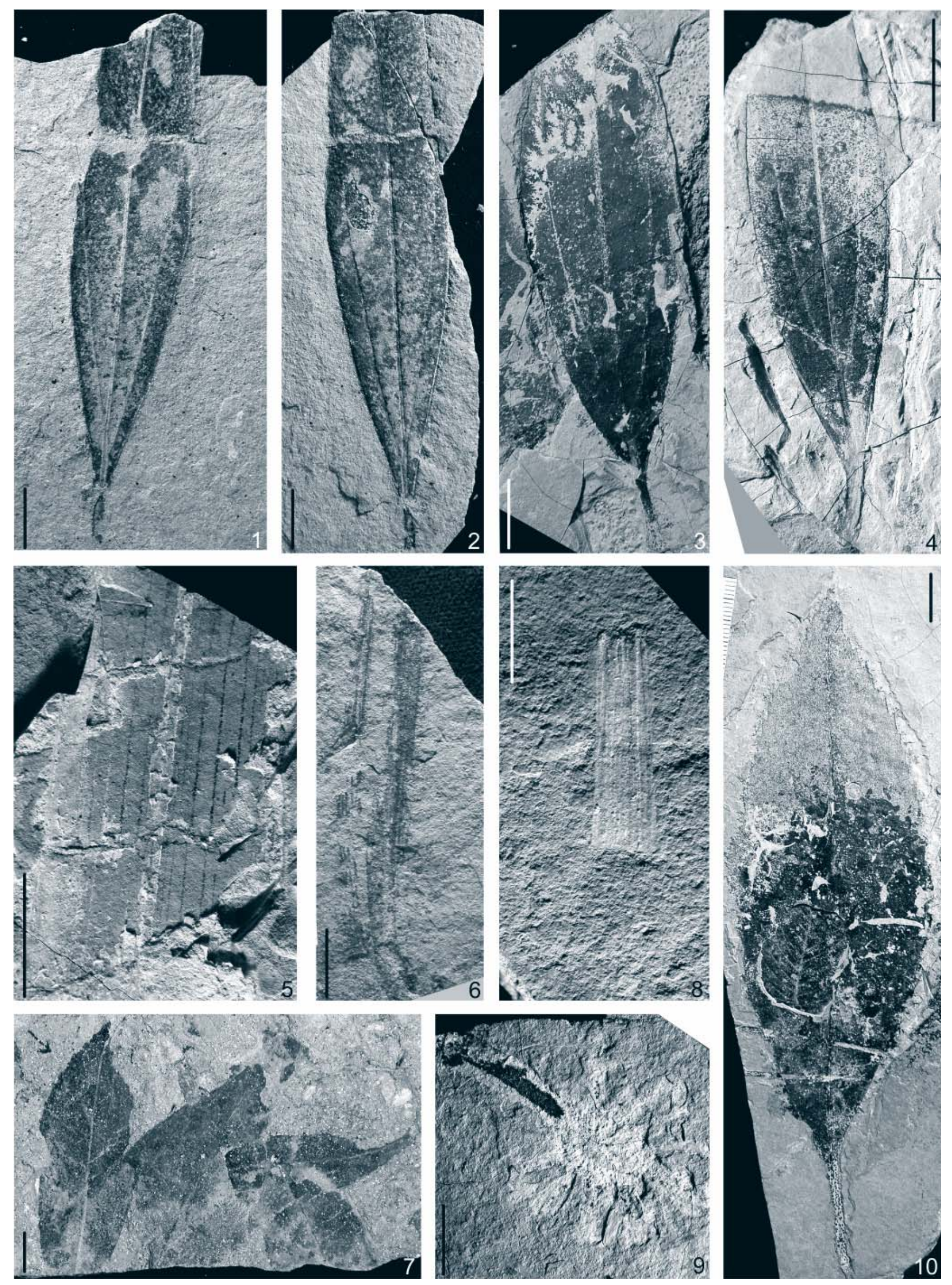
PLATE 5

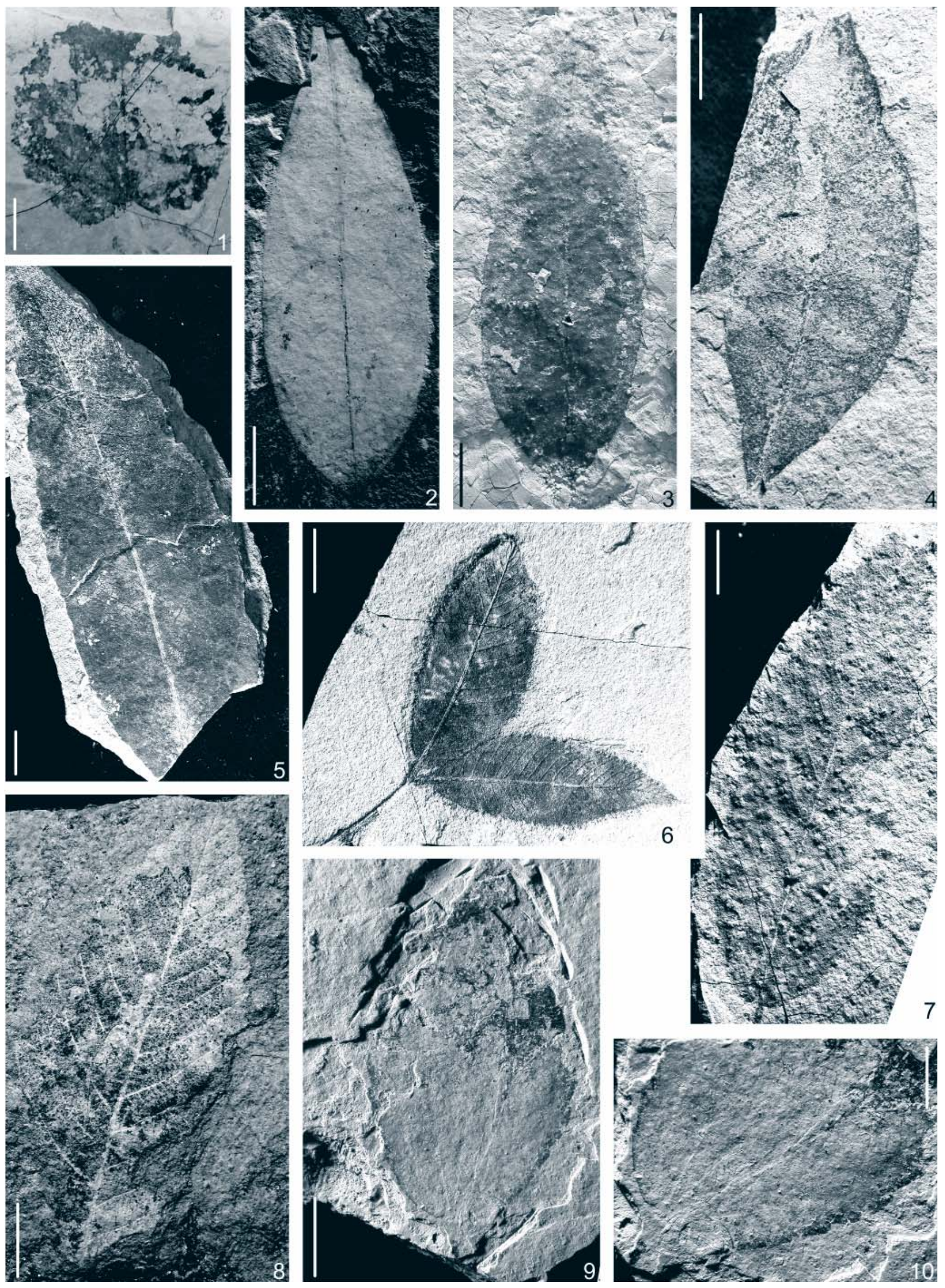




\section{PLATE 6}
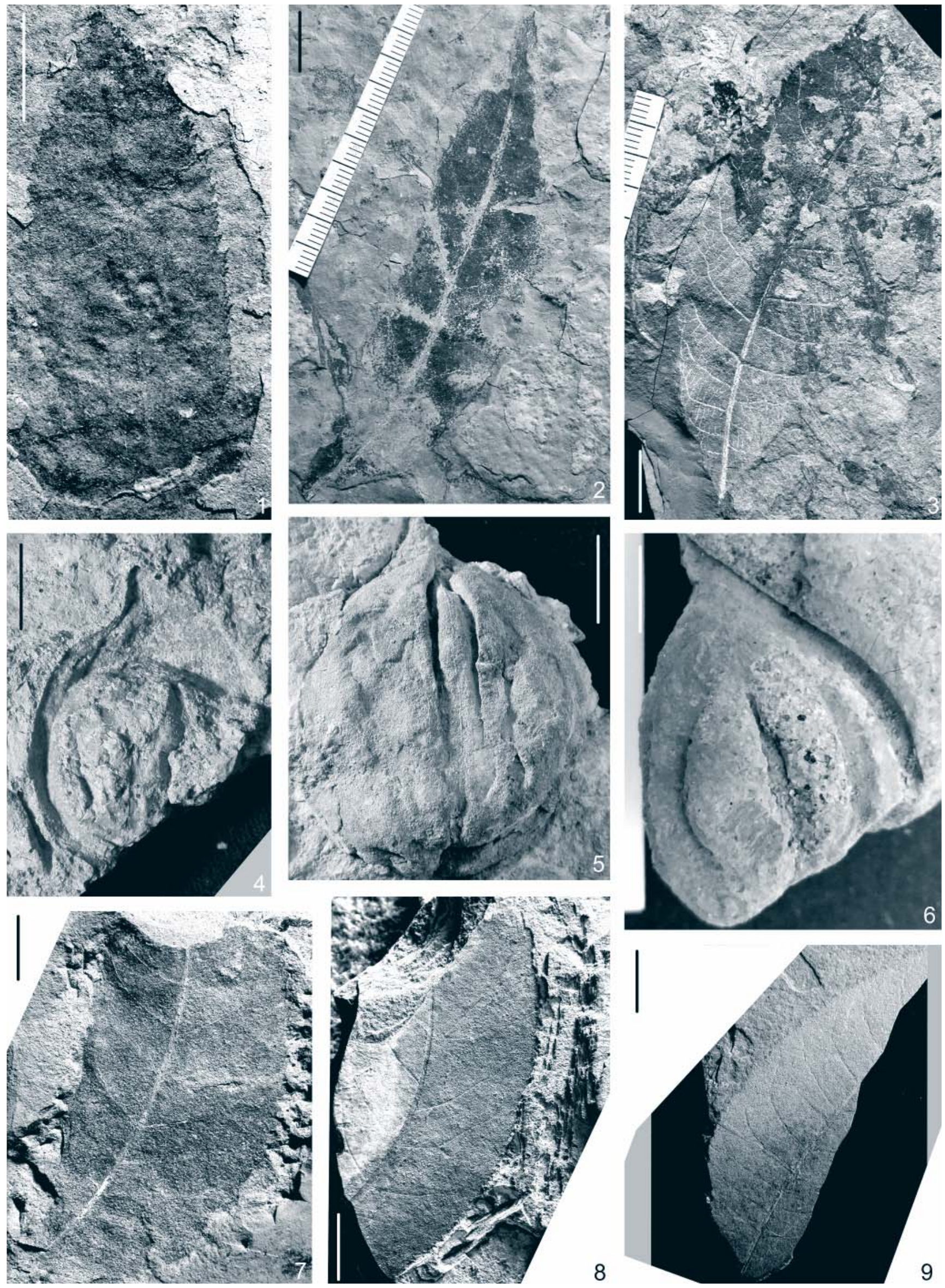
PLATE 7
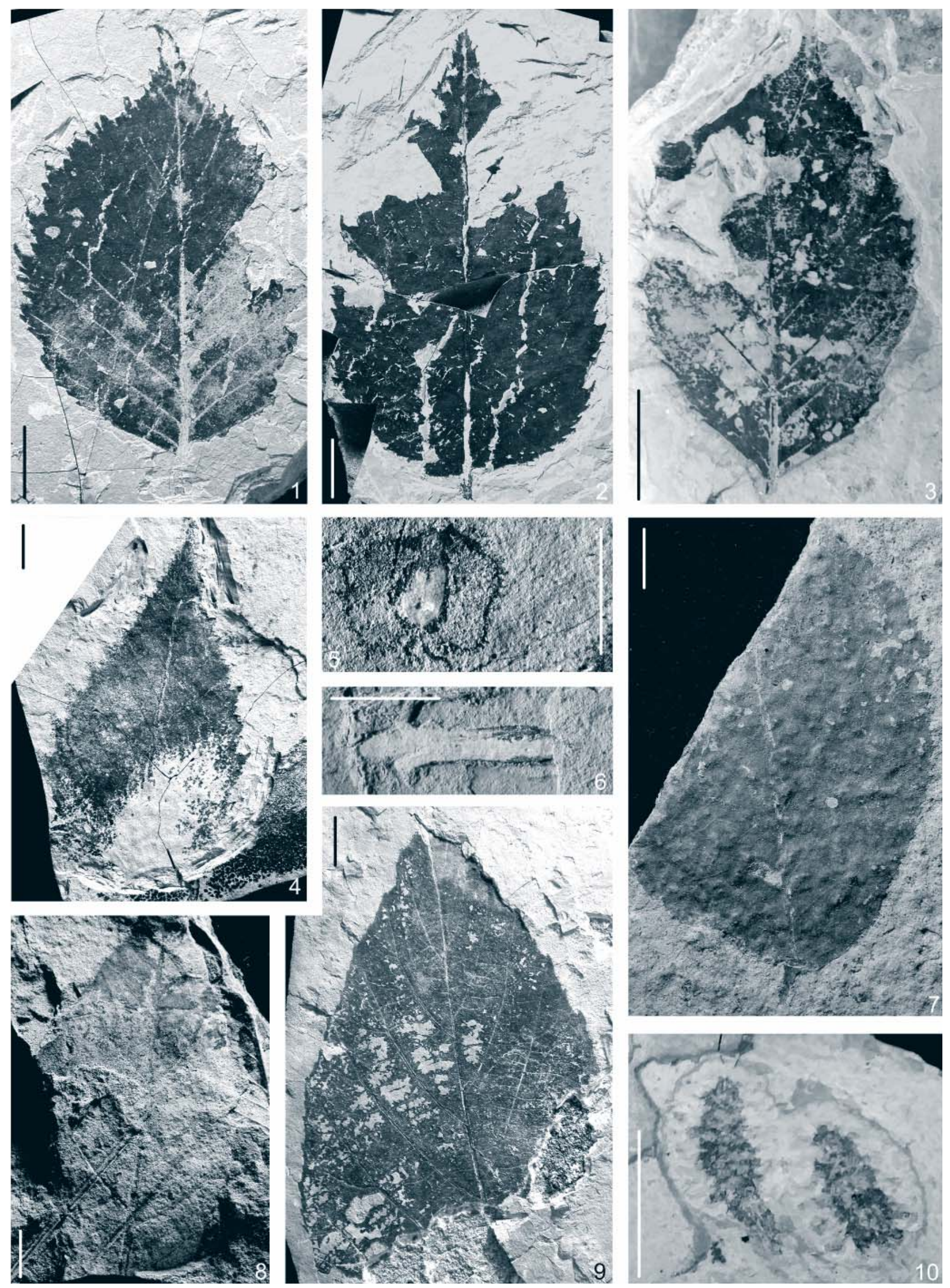


\section{PLATE 8}
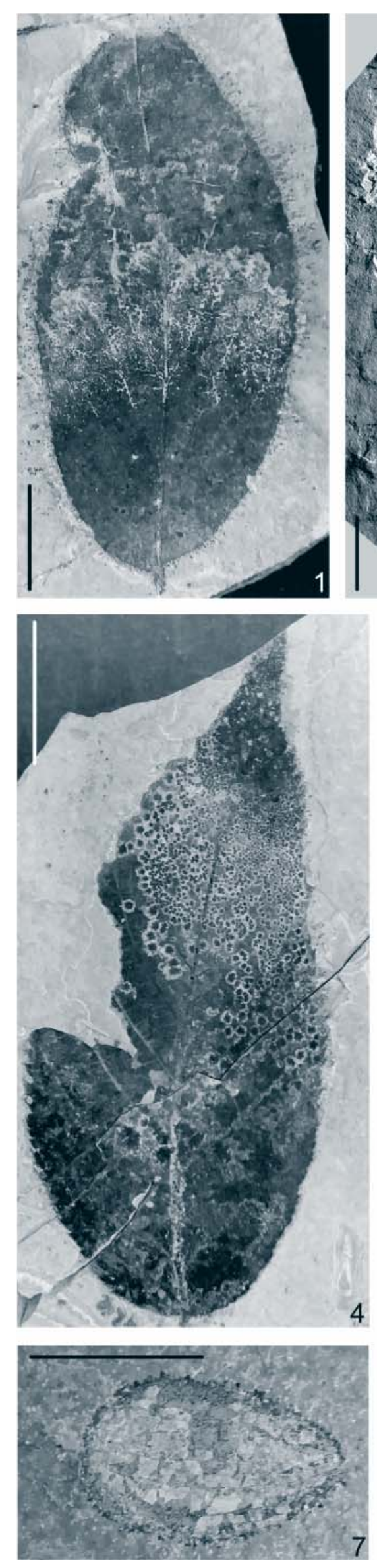

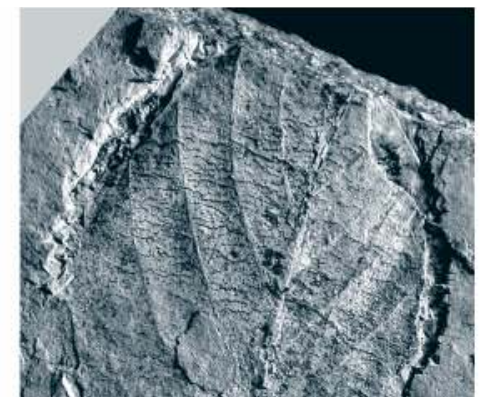

2. $y^{2} y^{2} y$
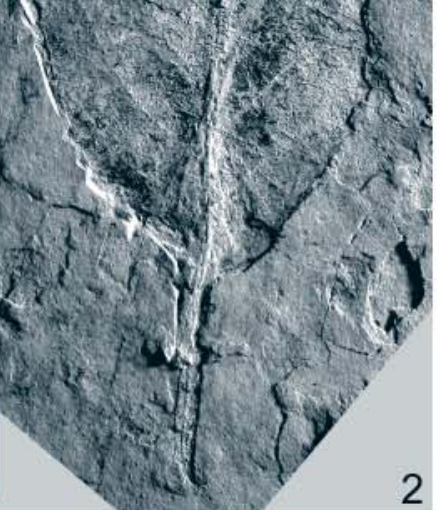

2
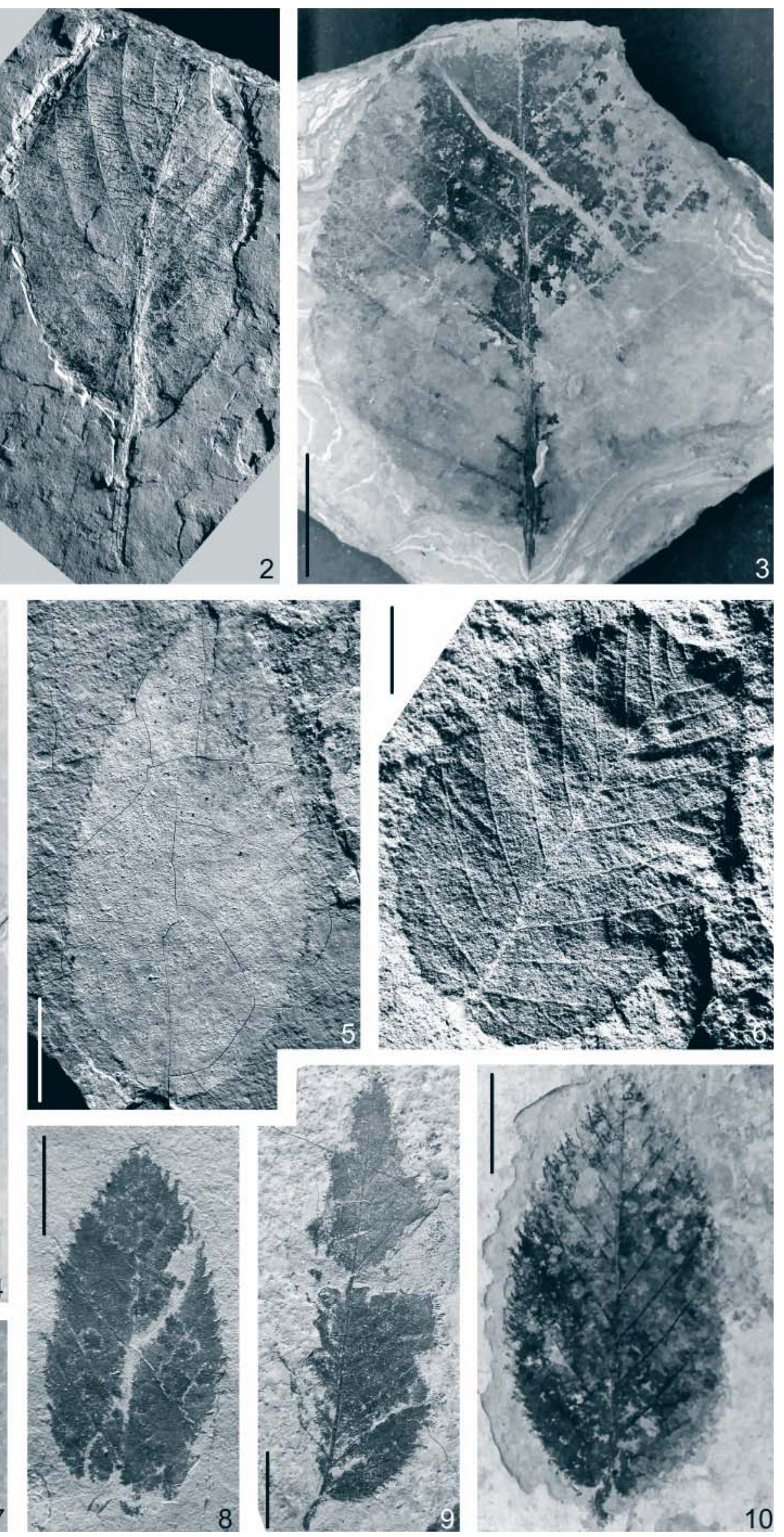

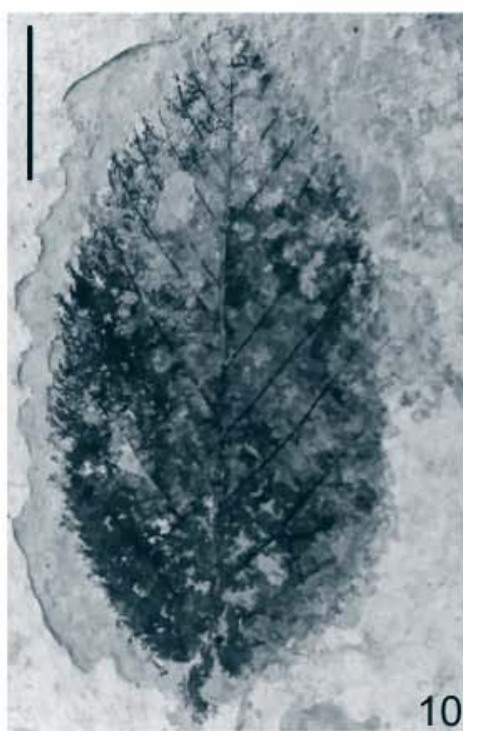


PLATE 9
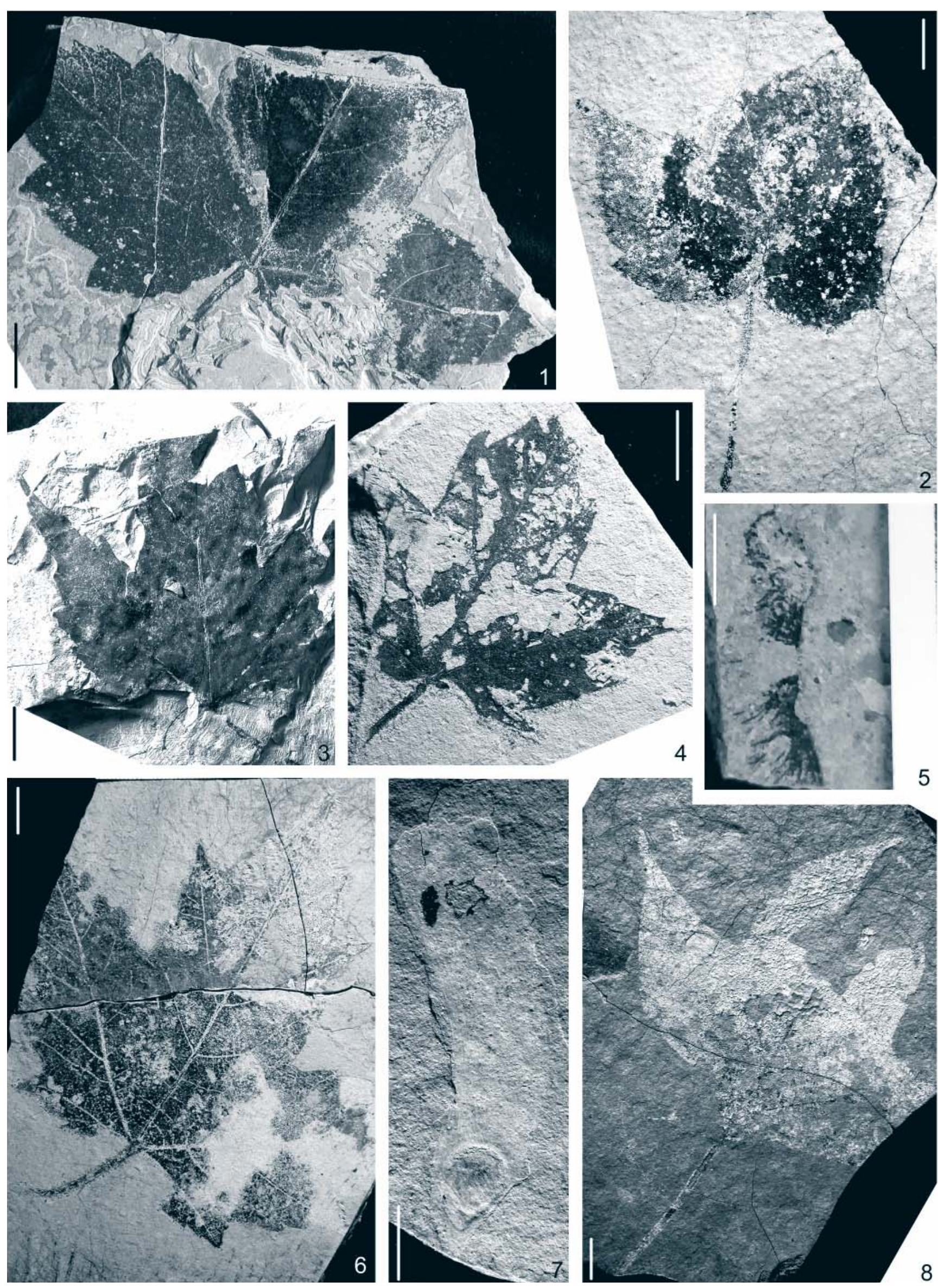


\section{PLATE 10}
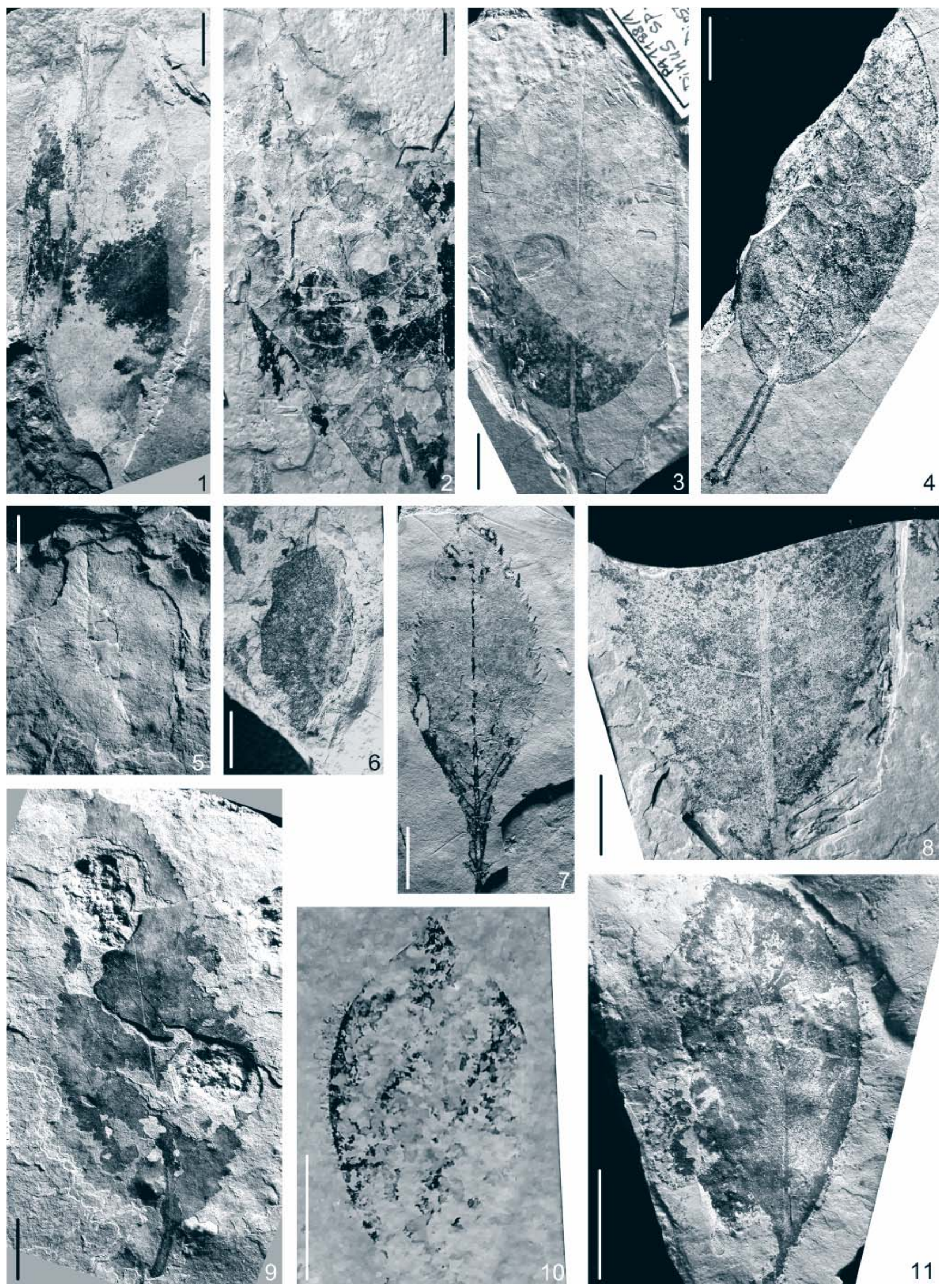